\title{
Discovery of a novel iota carrageenan sulfatase isolated from the marine bacterium Pseudoalteromonas
}

\section{carrageenovora}

\section{Sabine M. Genicot ${ }^{1,2 *}$, Agnès Groisillier ${ }^{1,2}$, Hélène Rogniaux ${ }^{3}$, Laurence Meslet-Cladière ${ }^{1,2,4}$, Tristan Barbeyron ${ }^{1,2}$ and William Helbert ${ }^{1,2,5}$}

1 UMR 8227, Integrative Biology of Marine Models, Station Biologique de Roscoff, Sorbonne Universités, UPMC Université Paris 06, Roscoff, France

2 UMR 8227, Centre National de la Recherche Scientifique, Integrative Biology of Marine Models, Station Biologique de Roscoff, Roscoff, France

${ }^{3}$ INRA, UR1268 Biopolymers Interactions Assemblies, Nantes, France

${ }^{4}$ EA3882, LUBEM, Technopôle Brest-Iroise, Université de Bretagne Occidentale, Plouzané, France

${ }^{5}$ Centre de Recherches sur les Macromolécules Végétales (CERMAV, UPR-CNRS 5301), Université Joseph Fourier, and Member of the Institut de Chimie Moléculaire de Grenoble (ICMG, FR-CNRS 2607), Grenoble, France

\section{Edited by:}

Antonio Trincone, Istituto di Chimica Biomolecolare, Consiglio Nazionale delle Ricerche, Italy

Reviewed by:

David J. Vocadlo, Simon Fraser University, Canada

Zvyagintseva Tatiana, Far-Eastern Branch, The Russian Academy of Sciences, Russia

*Correspondence:

Sabine M. Genicot, UMR 8227,

Centre National de la Recherche

Scientifique, Integrative Biology of Marine Models, Station Biologique de Roscoff, Place Georges Teissier, 29680 Roscoff, France

e-mail: genicot@sb-roscoff.fr
Carrageenans are sulfated polysaccharides extracted from the cell wall of some marine red algae. These polysaccharides are widely used as gelling, stabilizing, and viscosifying agents in the food and pharmaceutical industries. Since the rheological properties of these polysaccharides depend on their sulfate content, we screened several isolated marine bacteria for carrageenan specific sulfatase activity, in the aim of developing enzymatic bioconversion of carrageenans. As a result of the screening, an iota-carrageenan sulfatase was detected in the cell-free lysate of the marine bacterium Pseudoalteromonas carrageenovora strain $\mathrm{Psc}^{\top}$. It was purified through Phenyl Sepharose and Diethylaminoethyl Sepharose chromatography. The pure enzyme, PsC ı-CgsA, was characterized. It had a molecular weight of $115.9 \mathrm{kDaltons}$ and exhibited an optimal activity/stability at $\mathrm{pH} \sim 8.3$ and at $40 \pm 5^{\circ} \mathrm{C}$. It was inactivated by phenylmethylsulfonyl fluoride but not by ethylene diamine tetraacetic acid. PSC ı-CgsA specifically catalyzes the hydrolysis of the 4-S sulfate of iota-carrageenan. The purified enzyme could transform iota-carrageenan into hybrid iota-/alpha- or pure alpha-carrageenan under controlled conditions. The gene encoding PSC I-CgsA, a protein of 1038 amino acids, was cloned into Escherichia coli, and the sequence analysis revealed that PSC I-CgsA has more than 90\% sequence identity with a putative uncharacterized protein Q3IKL4 from the marine strain Pseudoalteromonas haloplanktis TAC 125, but besides this did not share any homology to characterized sulfatases. Phylogenetic studies show that $P$. carrageenovora sulfatase thus represents the first characterized member of a new sulfatase family, with a C-terminal domain having strong similarity with the superfamily of amidohydrolases, highlighting the still unexplored diversity of marine polysaccharide modifying enzymes.

Keywords: sulfatase, novel family, iota carrageenan, marine bacteria, sulfated polysaccharides, bioconversion

\section{INTRODUCTION}

Although sulfated biomolecules are present throughout the tree of life in terrestrial and marine environments, most of the sulfated carbohydrates are found in the marine environment, as illustrated by the structural diversity of sulfated polysaccharides encountered in the cell wall of macroalgae (Lahaye and Robic, 2007; Pomin and Mourao, 2008; Popper et al., 2011; Usov, 2011). As such polysaccharides are absent in the cell wall of fresh water and land plants; their loss has been postulated to be a consequence of the land colonization (Michel et al., 2010). These polysaccharides are thought to be involved in the phenomena of ionic and osmotic regulations. They are supposed to confer to the algae resistance to water currents and, due to their highly soluble nature, they allow water retention thereby slowing the drying of the algae at low tide (Kloareg and Quatrano, 1988).

The cell wall sulfated galactans of the red algae, referred to as agars or carrageenans, consist of a linear backbone of galactose residues linked by alternating $\beta-1,4$ and $\alpha-1,3$ glycosidic bonds. While all the $\beta$-linked residues are in the $\mathrm{D}$ configuration $(\mathrm{G}$ monomer), the $\alpha$-linked galactose units are in the L configuration in agars (L monomer) and in the D configuration in carrageenans (D monomer). In carrageenans, the repeating disaccharide units are classified according to the number and the position of ester sulfate (S) and by the presence of a 3,6-anhydro-bridge (DA) in the 4-linked residue (Knutsen et al., 1994). DA units are found in gelling carrageenans such as the kappa ( $\kappa$; G4S-DA) and the 
iota ( such as methyl or pyruvate groups, have also been observed, increasing the diversity of carrageenans which depends also on the algal source, the growth conditions and the extraction procedures (Pereira and Mesquita, 2004; Pereira et al., 2009). The physico-chemical properties of carrageenans, which are extensively used as thickeners and stabilizers in the food and cosmetic industries (de Ruiter and Rudolph, 1997), depend on their molecular weight, the occurrence of anhydrogalactose and their sulfate content and it is well established that higher levels of ester sulfate induce a decrease of the gel strength (Necas and Bartosikova, 2013). The use of specific enzymes to modify the sulfate pattern of carrageenans would therefore offer a biotechnological approach to control their sulfate content and thereby their rheological properties.

The heterogeneous structure of carrageenans, their gelling properties, and their interactions with the other components of red algal cell walls challenge the microorganisms using these polymers as carbon and energy sources. To breakdown the complex polysaccharides, marine bacteria secrete specific glycoside hydrolases (GHs), referred to as agarases and carrageenases, which catalyze the hydrolysis of the $\beta-1,4$ glycosidic bond between two galactopyranose units of their respective substrate (Michel et al., 2006). However, these enzymes are not sufficient alone to lead to the complete substrate assimilation. As revealed by the increasing number of sequenced marine microbial genomes, marine bacteria possess a large number of sulfatases. Although their precise function has not been elucidated yet, it is likely that they play an important role in the degradation of algal sulfated polysaccharides (Glöckner et al., 2003).
While genomic and metagenomic approaches offer promising strategies for marine biodiscovery (Ekborg et al., 2006; Shin et al., 2010), there are still some limitations, as screening of such libraries is indeed either sequence based or function based (Kennedy et al., 2008). These limitations sometimes do not allow assigning new functions to proteins annotated as hypothetical, and in such cases, it is still necessary to go through the isolation and purification of a defined activity in order to ascribe a function to a gene.

As both exo- and endo-acting sulfatases have been demonstrated in the case of glycoaminoglycans, we postulate their existence in the case of carrageenans. We therefore screened marine bacteria for endo-sulfatases to specifically modify the sulfation pattern of carrageenans in a polymeric state. In a previous work, a carrageenan sulfatase converting $\mathrm{l}$ - in $\alpha$-carrageenan was isolated from $P$. atlantica T6C and recombinantly overexpressed (Préchoux et al., 2013). Analysis of its mode of action confirmed the endo-character of this sulfatase removing the sulfate ester groups, most likely in a random pattern along the polysaccharide chain. Aiming at monitoring the physico-chemical properties of carrageenan, we were looking for further sulfatases potentially having different properties as this would allow to fine tune the rheological properties of these hydrocolloids or to adapt to different industrial conditions. In this context, we isolated and purified to homogeneity an endo-sulfatase from the marine bacterium $P$. carrageenovora $\mathrm{Psc}^{\mathrm{T}}$. Despite the fact that this enzyme has the same specificity as the $\mathrm{l}$-carrageenan sulfatase from $P$. atlantica (Préchoux et al., 2013), sequence analysis revealed that the $P$. carrageenovora sulfatase did not share any homology to already known sulfatases. It has, however, more than

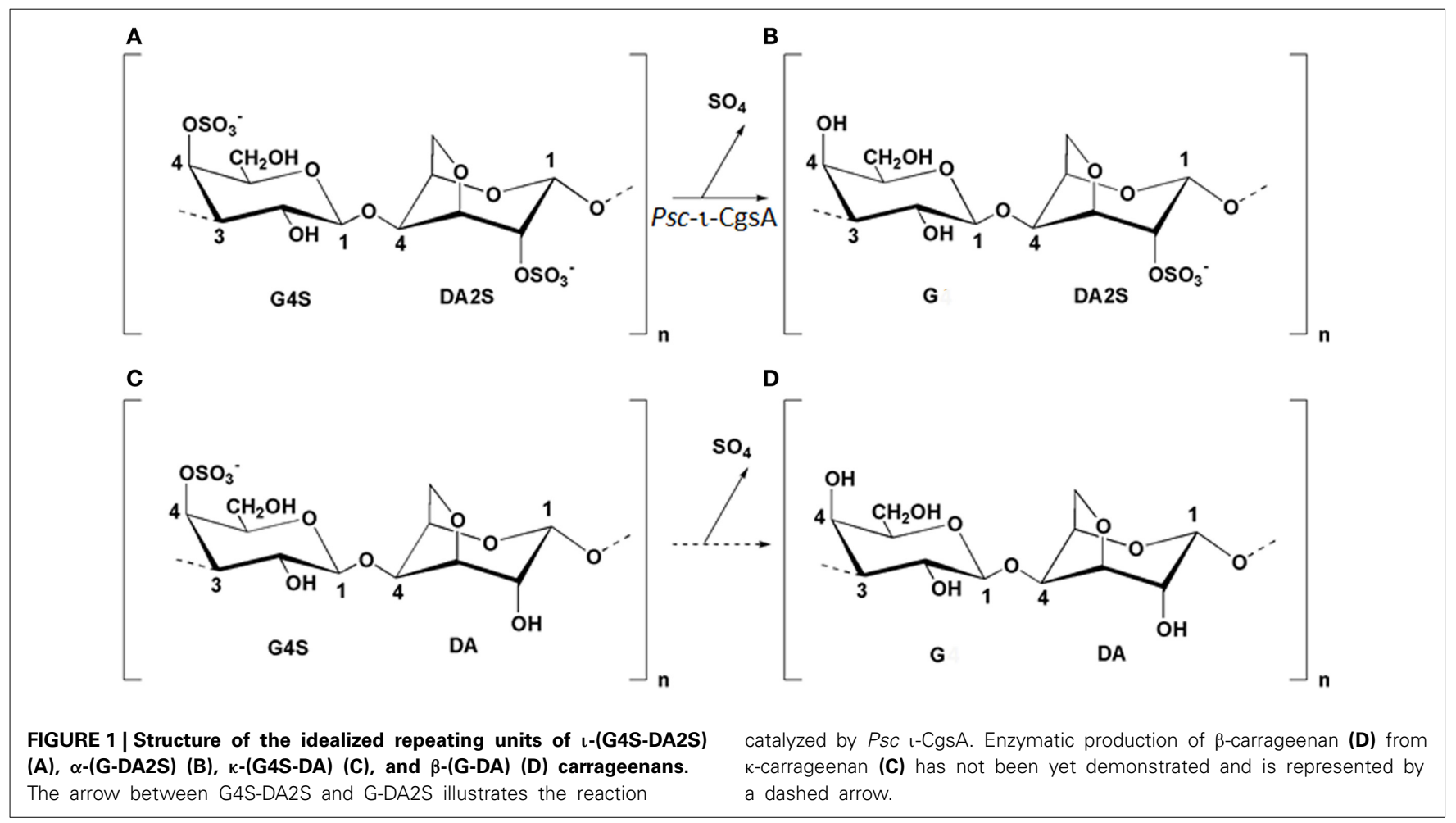


90\% sequence identity with a putative uncharacterized protein, Q3IKL4, from the marine strain Pseudoalteromonas haloplanktis TAC 125. Phylogenetic studies show that P. carrageenovora sulfatase thus represents the first characterized member of a new sulfatase family, with a C-terminal domain having strong similarity with the superfamily of amidohydrolases, highlighting the still unexplored diversity of marine polysaccharide modifying enzymes.

\section{MATERIALS AND METHODS MATERIALS}

$\lambda$-carrageenan (GENU X-7055) was extracted from tetrasporophytic plants of Gigartina skottsbergii, $\kappa$-carrageenan (GENU X-6913) was extracted from Eucheuma cottonii and ı-carrageenan (GENU X-6908) was extracted from Eucheuma spinosum. All of these samples were kindly provided by CP Kelco (Copenhagen). The marine bacteria P. carrageenovora strain Psc $^{\mathrm{T}}$ (ATCC $43555^{\mathrm{T}}$ ) (Bellion et al., 1982) and Pseudoalteromonas haloplanktis $545^{\mathrm{T}}$ $\left(\mathrm{DSMZ} 6060^{\mathrm{T}}\right)$ were obtained from the American Type Culture Collection and the Deutsche Sammlung von Mikroorganismen und Zellkulturen collection respectively.

\section{PRODUCTION AND PURIFICATION OF THE I-CARRAGEENAN SULFATASE FROM P. carrageenovora (PSC I-CgsA)}

Unless otherwise stated, all purification steps were performed at $4^{\circ} \mathrm{C}$. Hydrophobic interaction chromatography and anion exchange chromatography were carried out at $18^{\circ} \mathrm{C}$. P. carrageenovora strain $\mathrm{Psc}^{\mathrm{T}}$ was grown in $5 \mathrm{~L}$ of sulfate free ZoBell medium (ZoBell, 1941) containing $1 \mathrm{~g} \mathrm{~L}^{-1}$ of $\lambda$-carrageenan. After $36 \mathrm{~h}$ of incubation at $15^{\circ} \mathrm{C}$, the culture medium was centrifuged for $60 \mathrm{~min}$ at $1400-1800 \mathrm{~g}$. The supernatant was discarded and the cells were slowly suspended for about $1 \mathrm{~h}$ in $30 \mathrm{~mL}$ of buffer A ( $50 \mathrm{mM}$ Tris- $\mathrm{HCl}, \mathrm{pH} 8.3$ ) before lysis with a French Press. The lysate was centrifuged for $1 \mathrm{~h}$ at $29000 \mathrm{~g}$. The cell-free supernatant was brought to $30 \%\left(\mathrm{NH}_{4}\right)_{2} \mathrm{SO}_{4}$ saturation $\left(16.4 \mathrm{~g}\left(\mathrm{NH}_{4}\right)_{2} \mathrm{SO}_{4}\right.$ per $100 \mathrm{~mL}$ of extract) by slow addition of $\left(\mathrm{NH}_{4}\right)_{2} \mathrm{SO}_{4}$ salt. The sample was then centrifuged for $1 \mathrm{~h}$ at $25000 \mathrm{~g}$ and the $\mathrm{pH}$ of the supernatant was adjusted to 8.3 with $1 \mathrm{M}$ Tris- $\mathrm{HCl}$ buffer before being loaded on a Phenyl Sepharose 6 fast flow high sub column $(2.0 \times 19.5 \mathrm{~cm}$; GE Healthcare) equilibrated in buffer $\mathrm{B}\left(30 \%\right.$ saturation $\left(\mathrm{NH}_{4}\right)_{2} \mathrm{SO}_{4}$ in $50 \mathrm{mM}$ Tris- $\mathrm{HCl}, \mathrm{pH} 8.3$ ). The stationary phase was washed with buffer $\mathrm{B}$ at a flow rate of $1.5 \mathrm{~mL} \mathrm{~min}^{-1}$ until the absorbance at $280 \mathrm{~nm}$ of the effluent was negligible. Elution of the bound proteins was then achieved at the same flow rate by applying a linear decreasing gradient from buffer $\mathrm{B}$ to buffer $\mathrm{A}$ during 20 column volumes (CVs). Fractions of $6.5 \mathrm{~mL}$ were collected.

The active fractions were pooled and dialyzed for $96 \mathrm{~h}$ against buffer A. The desalted sample (about $140 \mathrm{~mL}$ ) was loaded at a flow

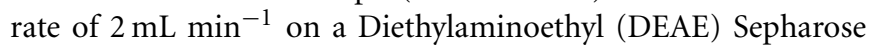
fast flow column $(1.6 \times 13 \mathrm{~cm}$; GE Healthcare $)$ equilibrated in buffer A. The column was washed at the same flow rate with buffer A until the absorbance measured at $280 \mathrm{~nm}$ was negligible. Elution of bound proteins was achieved at a flow rate of $2 \mathrm{~mL}$ $\min ^{-1}$ with a linear increasing gradient from 0 to $1 \mathrm{M} \mathrm{NaCl}$ in buffer A. The final concentration of $\mathrm{NaCl}$ was reached after 20
CVs and $5.5 \mathrm{~mL}$ fractions were collected. The fractions containing pure Psc l-CgsA were pooled and stored at $4^{\circ} \mathrm{C}$ in buffer A.

At the different steps of purification, the fractions were tested for sulfatase activity using standard $\iota$-carrageenan as substrate. The standard reaction mixture contained $100 \mu \mathrm{L}$ of protein fraction and $100 \mu \mathrm{L}$ of $1.2 \%(w / v)$ l-carrageenan both in $50 \mathrm{mM}$ Tris$\mathrm{HCl}$ buffer, $\mathrm{pH} 8.3$. Incubation was performed for $12 \mathrm{~h}$ at $35^{\circ} \mathrm{C}$. The reaction was stopped by diluting the incubation medium 2fold and by centrifuging the samples in a Microcon-10 (Millipore) to remove the carrageenan. For each sample, the corresponding blank was performed in the same conditions but using the sample previously boiled for $10 \mathrm{~min}$. The amount of free sulfate present in the filtrate was assayed by high pressure anion exchange chromatography (HPAEC) using a Dionex 500 chromatography system as described previously (Genicot-Joncour et al., 2009). Briefly, the anions present in the reaction medium were separated on an AS11 anion-exchange column $(4 \times 200 \mathrm{~mm}$, Dionex $)$ equipped with an AG11 guard column $(4 \times 50 \mathrm{~mm}$, Dionex). Elution was performed with an isocratic gradient of $12 \mathrm{mM}$ $\mathrm{NaOH}$ at a flow rate of $1 \mathrm{~mL} \mathrm{~min}^{-1}$ using a GP40 gradient pump (Dionex). Detection of the anions was carried out with an ED40 electrochemical detector in the conductivity mode. The peak of sulfate eluted separately from the other ions at $3 \mathrm{~min}$ and the concentration of sulfate was deduced from the signal intensity and calculated from a standard sulfate calibration curve. The active fractions were analyzed by SDS-PAGE (Laemmli and Favre, 1973 ) using 12\% Criterion precast Bis-Tris gels (Bio-Rad). Gels were stained routinely with Coomassie blue R-250 and colloidal Coomassie blue staining when subjected to mass spectrometry analyses (Candiano et al., 2004). Protein quantification was performed according to Bradford (1976) using the Bio-Rad protein assay. Bovine serum albumin was used as a standard. Protein concentration of pure sulfatase was also estimated at $280 \mathrm{~nm}$ using a Nanodrop 2000 Spectrophotometer (Thermofisher). A molar extinction coefficient of $172.120 \mathrm{M}^{-1} \mathrm{~cm}^{-1}$ and a molecular weight of $115.916 \mathrm{kDaltons}(\mathrm{kDa})$, both deduced from the protein sequence (see below), were used to calculate the concentration of the enzyme.

\section{PROTEIN SEQuence determination OF THE Psc ו-CgsA PROTEIN}

The band corresponding to the Psc l-CgsA sulfatase was excised from Coomassie blue stained SDS-PAGE and was subjected to ingel tryptic digestion as described in Larré et al. (2010). Briefly, the gel slice was washed with $100 \mu \mathrm{L}$ of $25 \mathrm{mM} \mathrm{NH}_{4} \mathrm{HCO}_{3}$, followed by dehydration with $100 \mu \mathrm{L}$ of $50 \%(v / v)$ acetonitrile in $25 \mathrm{mM} \mathrm{NH}_{4} \mathrm{HCO}_{3}$. Proteins were reduced and alkylated by incubation for $1 \mathrm{~h}$ at $57^{\circ} \mathrm{C}$ in the presence of $10 \mathrm{mM}$ Dithiothreitol (DTT), followed by $45 \mathrm{~min}$ of incubation at room temperature with $55 \mathrm{mM}$ iodoacetamide. The gel slice was further washed with $\mathrm{NH}_{4} \mathrm{HCO}_{3}$ and dehydrated as described before. The band was then incubated overnight at $37^{\circ} \mathrm{C}$ with $10 \mu \mathrm{L}$ of trypsin (sequencing grade, Promega) solubilized at $12.5 \mathrm{ng} \mu \mathrm{L}^{-1}$ in $25 \mathrm{mM} \mathrm{NH}_{4} \mathrm{HCO}_{3}$. The supernatant was collected and the tryptic fragments were analyzed by Matrix Assisted Laser Desorption Ionization coupled to a Time-of-Flight analyzer (MALDI-TOF) and nanoscale capillary liquid chromatography-tandem mass spectrometry (LC-MS/MS). MALDI-TOF mass spectrometry was 
performed on a M@LDI LR instrument (Waters). One microliter of the sample was mixed with $1 \mu \mathrm{L}$ of the matrix preparation (2.5 $\mathrm{g} \mathrm{L}^{-1} \alpha$-cyano-4-hydroxycinnamic, $2.5 \mathrm{~g} \mathrm{~L}^{-1}$ 2,5-dihydroxy benzoic acid, 70\% $(v / v)$ acetonitrile, and $0.1 \%(w / v)$ trifluoroacetic acid) and deposited onto the MALDI sample probe. Mass spectra were acquired on the mass-to-charge ratio range from 800 to 3000 . LC-MS/MS analysis was performed using a nanoflow high pressure liquid chromatography (HPLC) system (Switchos-Ultimate II, Dionex) coupled to a hybrid quadrupole orthogonal acceleration time-of-flight mass spectrometer (QTOF Global, Waters). Chromatographic separations were conducted on a reverse-phase capillary column (75 $\mu \mathrm{m}$ i.d., Pepmap $\mathrm{C} 18$, Dionex) at a flow rate of $200 \mathrm{~nL} \mathrm{~min}^{-1}$ using a gradient from 2 to $50 \%$ of $0.08 \%(w / v)$ formic acid in acetonitrile. Mass data were recorded in "data dependent" mode: one MS spectrum was recorded on the mass-to-charge ratio range 400 to 1500 within $1 \mathrm{~s}$, after which the three most intense ions were selected and fragmented in the collision cell. Raw data obtained by MALDI-TOF or LC-MS/MS were processed by means of the Protein Lynx Global Server v. 2.1. Software (Waters).

Protein identification was carried out by comparing the collected LC-MS/MS data against Uniprot databank. Databank searches were performed through the use of the Mascot server v. 2.2. program (Matrix Science). The mass tolerance was set to 120 parts per million (ppm) for parent ions (MS mode) and 0.3 Da for fragment ions (MS/MS mode), and one missed cut per peptide was allowed. Some MS/MS spectra were de-novo sequenced using the Protein Lynx Global Server v. 2.1. Software. This procedure was facilitated by the use of the OVNIp program (Tessier et al., 2010).

\section{CLONING, HETEROLOGOUS EXPRESSION AND PURIFICATION OF THE Psc ı-CgsA}

Genomic DNA from $P$. carrageenovora Psc $^{\mathrm{T}}$ was prepared as previously described (Barbeyron et al., 1984). The primers forward (5'-CCCCCCGAATTCTTATTTGTTGTTTTCAAAATAAAGTG GTTTAC-3'; EcoRI restriction site is underlined) and reverse (5'-GGGGGGGGATCCCAACAAGACGATGAGCCAAAATGG-

$3^{\prime}$; BamHI restriction site is underlined), deduced from the gene PSHAa1171 of $P$. haloplanktis TAC 125 (Uniprot accession number Q3IKL4), were used to amplify the Psc $\iota$-cgsA gene. The SignalP 3.0 program (Bendtsen et al., 2004) predicted the presence of a signal peptide with a cleavage site between residues $\mathrm{Ala}^{22}$ and $\mathrm{Gln}^{23}$ in the Q3IKL4 protein. Here, the gene without the signal peptide was cloned in between the BamHI/EcoRI sites of the expression vector pFO4 (Groisillier et al., 2010) which encompass an N-terminal fused six-histidine-tag (6 His-tag). The sequence of the gene was checked using a genetic analyzer ABI 3130xl (Applied Biosystems) equipped with $50 \mathrm{~cm}$ capillaries and POP ${ }^{\mathrm{TM}}$ polymer. The amplified and verified gene sequence of Psc l-cgsA was deposited at GenBank with accession number JN228253. The Psc $\iota-\operatorname{cgs} A$ gene was also optimized for Escherichia coli codon use by GENEART (Life Technologies), amplified using the forward primer (5'-CCGGGGATCCCAGCAGGAT GATGAACCG-3'; Bam $\mathrm{HI}$ restriction site is underlined) and the reverse primer $\left(5^{\prime}\right.$-GGCCGAATTCTTATTTGTTATTTTCAAA
ATACAG-3'; EcoRI restriction site is underlined) and cloned into the same expression vector.

For protein expression, transformed E. coli strains BL21(DE3) $\left(\right.$ Novagen $^{\mathrm{R}}$ ) were either grown at $20^{\circ} \mathrm{C}$ for $72 \mathrm{~h}$ in ZYP 5052 medium containing $200 \mu \mathrm{g} . \mathrm{mL}^{-1}$ ampicillin (Studier, 2005) or in Luria Bertani (LB) medium. In the latter case, the recombinant $E$. coli BL21 (DE3) cells were grown at $37^{\circ} \mathrm{C}$ in $\mathrm{LB}$ medium containing $100 \mu \mathrm{g} \cdot \mathrm{mL}^{-1}$ ampicillin and $0.025 \%(w / v)$ glucose until the optical density at $600 \mathrm{~nm}$ reached $\sim 1.2-1.5$. The culture medium was then diluted twice with an equal volume of cold LB medium and buffered with HEPES buffer $\mathrm{pH} 7$ to a $20 \mathrm{mM}$ final concentration. Induction was performed by addition of lactose $(0.6 \%)$ and isopropyl $\beta$-D-1-thiogalactopyranoside (IPTG) (2 mM) (Korf et al., 2005). The cultivation was further continued for $\sim 18 \mathrm{~h}$ at $20^{\circ} \mathrm{C}$ until the optical density at $600 \mathrm{~nm}$ reached $\sim 5-8$. E. coli BL21 (DE3) bearing pFO4 without insert was used as the negative control. Culture was stopped by centrifugation at $1400-1800 \mathrm{~g}$ for $60 \mathrm{~min}$. The pellet was then suspended in $50 \mathrm{mM}$ Tris- $\mathrm{HCl}$ ( $\mathrm{pH} 8.3$ ) buffer containing $200 \mathrm{mM} \mathrm{NaCl}$ and $15 \mathrm{mM}$ imidazole (buffer C) before lysis with a French Press. The lysate was centrifuged for $1 \mathrm{~h}$ at 29,000 $\mathrm{g}$. The cell-free supernatant was then $0.2 \mu \mathrm{M}$ filtered before being loaded onto a HisPrep FF $16 / 10$ column $(1.6 \times 10 \mathrm{~cm}$, GE Healthcare $)$ equilibrated in buffer C. Elution of the protein was performed in buffer $\mathrm{C}$ using a linear gradient, increasing from $15 \mathrm{mM}$ to $500 \mathrm{mM}$ imidazole. The final concentration of imidazole was reached after $10 \mathrm{CVs}$ and $2 \mathrm{~mL}$ fractions were collected. Fractions containing the recombinant tagged enzyme were estimated by SDS-PAGE analysis and by Western blot. Transfer from SDS gel onto ready to use $0.2 \mu \mathrm{m}$ nitrocellulose membrane (BioRad) was performed using a Trans Blot Turbo system in the conditions specified by the manufacturer (BioRad). Monoclonal anti-polyhistidine peroxidase conjugate (Sigma) was used at a final concentration of $1 / 10,000$ to specifically recognize the his-tagged fusion proteins. Immuno-detection was performed by chemiluminescence using the Clarity Western ECL Substrate kit (BioRad) and visualization was achieved using the Chemi-Capt 50001 software. Recombinant enzyme activity was tested using 4- methylumbeliferyl sulfate (potassium salt, Sigma), further on called MUFS, as substrate. Unless explicitly indicated in the text, the standard conditions included 8-20 $\mu \mathrm{g}$ sulfatase, $50 \mathrm{mM}$ Tris- $\mathrm{HCl} \mathrm{pH} 8.3,200 \mathrm{mM} \mathrm{NaCl}, 850 \mu \mathrm{M}$ MUFS in a $150 \mu \mathrm{l}$ reaction volume. The reaction was carried out for up to $120 \mathrm{~min}$ at $35^{\circ} \mathrm{C}$ and the increase of absorbance was measured as a function of time at $360 \mathrm{~nm}$ using a Saphire 2 microplate reader (Tecan, Männedorf, Switzerland). For each reaction, a blank was made using the negative control at the same protein concentration than that of the sample.

\section{BIOCHEMICAL CHARACTERIZATION OF THE NATIVE PsC I-CgsA}

Sulfatase activity of the native enzyme was characterized using ı-carrageenan as substrate and the amount of sulfate released was determined by HPAEC as described above. $\mathrm{pH}$ optimum determination was performed at $35^{\circ} \mathrm{C}$ in a $\mathrm{pH}$ range of 5.8-9.5. Assays were carried out by incubating $50 \mu \mathrm{l}$ of $\mathrm{l}$-carrageenan $(1.8 \% w / v$ in water) with $80 \mu \mathrm{l}$ of $500 \mathrm{mM}$ buffer and $40 \mu \mathrm{l}$ of sulfatase solution $\left(600 \mu \mathrm{g} \mathrm{mL}^{-1}\right.$ in $50 \mathrm{mM}$ Tris- $\left.\mathrm{HCl} \mathrm{pH8}\right)$. The solutions used to buffer the reactions were as follows: $500 \mathrm{mM}$ 
2-(N-morpholino) ethanesulfonic acid (MES) ( $\mathrm{pH} 5.5$ to $\mathrm{pH}$ 6.9), $500 \mathrm{mM}$ Bis-Tris Propane ( $\mathrm{pH} 6.5$ to $\mathrm{pH} 9.5$ ) and $500 \mathrm{mM}$ Tris- $\mathrm{HCl}$ ( $\mathrm{pH} 7$ to $\mathrm{pH} 9$ ). The optimal temperature was determined by measuring the amount of sulfate released upon incubation of $35 \mu \mathrm{l}$ of sulfatase solution $\left(600 \mu \mathrm{g} \mathrm{mL}^{-1}\right)$ with $115 \mu \mathrm{l}$ of $\mathrm{\iota}$-carrageenan $(0.6 \%, w / v)$ both in $50 \mathrm{mM}$ Tris- $\mathrm{HCl} \mathrm{pH} 8.0$ in a range of $5-55^{\circ} \mathrm{C}$ in steps of $5^{\circ} \mathrm{C}$. The effect of ionic strength on enzyme activity was assessed using increasing $\mathrm{NaCl}$ concentration from 0 to $500 \mathrm{mM}$. The influence of phenylmethylsulfonyl fluoride (PMSF), magnesium chloride $\left(\mathrm{MgCl}_{2}\right)$, and DTT on the sulfatase activity was tested at final concentrations of 1 and $2 \mathrm{mM}$, whilst chelators agents were tested at final concentrations ranging from 2 to $10 \mathrm{mM}$. All these assays were performed at $30^{\circ} \mathrm{C}$ by incubating $50 \mu \mathrm{l}$ of $\mathrm{l}$-carrageenan $(1.5 \% \mathrm{w} / v$ in $50 \mathrm{mM}$ Tris- $\mathrm{HCl}$ pH8) with $20 \mu \mathrm{l}$ of sulfatase solution $\left(670 \mu \mathrm{g} \mathrm{mL}^{-1}\right)$ in $120 \mu \mathrm{l}$ total volume The relative activity was defined as the percentage of the activity observed without addition of these reagents.

\section{BIOCHEMICAL CHARACTERIZATION OF THE RECOMBINANT SULFATASE}

Sulfatase activity of the recombinant enzyme was characterized using MUFS in the standard conditions described above. The influence of $\mathrm{pH}$ on the activity was determined using the same buffers as for the native enzyme. The effect of different additives on the recombinant enzyme activity was studied in the same concentration conditions as those used for the characterization of the native enzyme. However, prior to the determination of the effect of ionic strength on the enzyme activity, the sample of recombinant enzyme was dialyzed overnight against $50 \mathrm{mM}$ Tris- $\mathrm{HCl}$ $\mathrm{pH}$ 8.3. In the same way as for the native enzyme, the relative activity was defined as the percentage of the activity observed without addition of these reagents.

\section{KINETIC PARAMETERS OF NATIVE AND RECOMBINANT Psc I-CgsA}

As the $\iota$-carrageenan is viscous even at low concentration, it was not possible to prepare a sufficient range of $\mathrm{l}$-carrageenan concentrations to allow for the accurate determination of kinetic parameters of the enzymes. For this reason, the Michaelis parameters of both enzymes, purified from $P$. carrageenovora culture medium and recombinantly expressed in E. coli, were determined at optimum conditions of the native enzyme, using MUFS as substrate. Kinetic measurements were conducted in $150 \mu \mathrm{l}$ final volume and $80 \mu \mathrm{l}$ of sulfatase were incubated with $2 \mu \mathrm{l}$ of MUFS at final concentrations ranging from 5.2 to $206.5 \mu \mathrm{M}$. The formation of methylumbelliferone was measured as a function of time at $360 \mathrm{~nm}$ (molar extinction coefficient of $5143 \mathrm{M}^{-1}$ $\mathrm{cm}^{-1}$ ) (Viladot et al., 1998), using a Saphire2 microplate reader (Tecan, Männedorf, Switzerland). The experiments were carried out in triplicates. Kinetic experiments were performed for up to $120 \mathrm{~min}$ at $35^{\circ} \mathrm{C}$. The initial velocities were measured on the linear section of the kinetics plots and the apparent $\mathrm{K}_{\mathrm{m}}$ and $\mathrm{V}_{\max }$ were calculated from an hyperbolic regression analysis using the software Hyper32 version 1.0.0. (http://homepage.ntlworld.com/ john.easterby).

\section{NUCLEAR MAGNETIC RESONANCE (NMR) SPECTROSCOPY}

The l-carrageenan incubated with pure native Psc ı-CgsA was freeze dried, exchanged twice with 99.97 atom $\%{ }^{2} \mathrm{H}_{2} \mathrm{O}$ and then dissolved in ${ }^{2} \mathrm{H}_{2} \mathrm{O}$ at a final concentration of $10 \mathrm{mg} \mathrm{mL}^{-1}$. The product was then transferred into a $5 \mathrm{~mm}$ NMR tube and ${ }^{1} \mathrm{H}$ NMR spectra were recorded at $70^{\circ} \mathrm{C}$, using a BRUKER Advance DRX 500 spectrometer equipped with an indirect $5 \mathrm{~mm}$ gradient probehead TXI ${ }^{1} \mathrm{H} /{ }^{13} \mathrm{C} /{ }^{31} \mathrm{P}$. Chemical shifts are expressed in $\mathrm{ppm}$ in reference to trimethylsilylpropionic acid (TSP), which was used as an external standard. No suppression of the HOD signal was performed.

\section{SEOUENCE AND PHYLOGENETIC ANALYSIS}

Searches for protein sequence similarities were performed in Uniprot database using the BlastP program (Altschul et al., 1997). Protein structure prediction was performed with the Phyre2 server (Kelley and Sternberg, 2009). A multiple alignment was generated with 421 sequences using the MAFFT program and LINS-i algorithm (Katoh et al., 2005) and manually refined. From the multiple alignments, 171 positions were used to build a phylogenetic tree by the Maximum Likelihood method using the Whelan and Goldman evolution model (Whelan and Goldman, 2001). Reconstruction of the tree and bootstrap analysis (resampling of 100) were conducted with the MEGA v. 5.05. Software (Tamura et al., 2011).

\section{RESULTS}

\section{SCREENING AND PURIFICATION OF THE PsC I-CgsA}

The marine bacterium $P$. carrageenovora was screened for potential sulfatase activity capable to catalyze the hydrolysis of sulfate from carrageenans. As a consequence the use of carrageenans as substrate was mandatory during the screening and the sulfate assay was performed by HPAEC as described previously (Genicot-Joncour et al., 2009). To avoid interference of ions with the detection of sulfate groups during chromatography analysis, $P$. carrageenovora strain $\mathrm{Psc}^{\mathrm{T}}$ was grown in ZoBell medium.

Carrageenan-sulfatase activities were detected only when the culture medium was supplemented with $\kappa$-, $\iota$ - or $\lambda$-carrageenan. As reported in Table 1, carrageenan-sulfatase activities were measured both in the bacterial pellet and in the culture supernatant. $\iota$ - and $\lambda$-carrageenan proved to be good inducers of carrageenansulfatases that were active on $\kappa-, \iota$ - and $\lambda$-carrageenan. In this study, we focus our attention on the $\iota$-carrageenan sulfatase activity detected in the pellet of $P$. carrageenovora cultures induced by the $\lambda$-carrageenan.

The newly detected enzyme, further on named Psc ı-CgsA, was purified by a combination of ammonium sulfate fractionation, hydrophobic interaction chromatography and ion exchange chromatography. The first chromatographic step using hydrophobic interaction chromatography on phenyl-Sepharose was efficient in purifying the sulfatase as this one elutes between 91 and $78 \mathrm{mS} \mathrm{cm}^{-1}$, just before the majority of the proteins (Figure $2 \mathrm{~A}$ ). All the active fractions were pooled and dialyzed before being loaded on top of the anion exchange chromatography column (DEAE Sepharose). At this stage, the sulfatase eluted between 300 and $370 \mathrm{mM} \mathrm{NaCl}$ i.e., 29.5 and $32.3 \mathrm{mS} \mathrm{cm}^{-1}$ respectively (Figure 2B). The purified enzyme gave a single band with an apparent molecular mass of $110 \mathrm{kDa}$ in SDS-PAGE under reducing conditions (Figure 2C). 
Table 1 | Sulfatase activity in cultures of $P$. carrageenovora $\mathrm{Psc}^{\top}$ and $P$. haloplanktis $545^{\top}$.

\begin{tabular}{|c|c|c|c|c|c|}
\hline & \multirow[t]{2}{*}{ Inducer } & \multirow[t]{2}{*}{ Total Proteins } & \multicolumn{3}{|c|}{ Substrate } \\
\hline & & & к-carrageenan & ı-carrageenan & $\lambda$-carrageenan \\
\hline \multirow[t]{3}{*}{ Supernatant } & к-carrageenan & $1.6(1.1)$ & n.d. (1.5) & n.d. (13.4) & 0.6 (n.d.) \\
\hline & ı-carrageenan & $1.6(0.5)$ & 6.3 (n.d.) & 11.9 (n.d.) & n.d. (n.d.) \\
\hline & $\lambda$-carrageenan & $2.35(0.8)$ & n.d. (n.d.) & n.d. (73.2) & $4.5(7.7)$ \\
\hline \multirow[t]{3}{*}{ Pellet } & к-carrageenan & $6.5(4.1)$ & 0.9 (n.d.) & n.d. (n.d.) & n.d. (n.d.) \\
\hline & ı-carrageenan & $10.5(3.8)$ & 4.0 (n.d.) & 4.7 (n.d.) & n.d. (n.d.) \\
\hline & $\lambda$-carrageenan & $30(5.9)$ & 2.1 (n.d.) & 10.4 (n.d.) & 0.4 (n.d.) \\
\hline
\end{tabular}

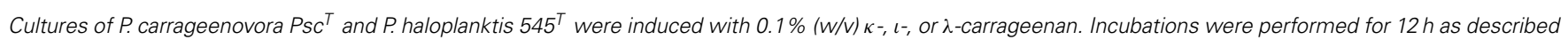

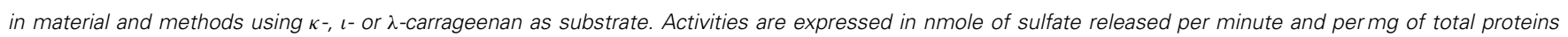

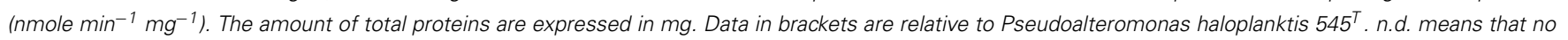
activity was detected.

\section{IDENTIFICATION OF THE Psc ı-CgsA PROTEIN, A NOVEL SULFATASE}

Following digestion of the pure Psc ı-CgsA protein by trypsin, the peptide fragments were analyzed by LC-MS/MS and compared to the Uniprot database. Eight peptides (YVEPTFSPDGK, VIENGVIITDGK, DLGEPMFSPDGR, SLGAGEVWLYHK, YVYFSHDATPGK, FTQNLDTDEFDVK, LLNSPAWSPDGDYLVAR, VSPDGQYLAFAER) were identical to peptides found in a putative uncharacterized protein Q3IKL4 (117.873 kDa), encoded in the genome of the marine strain P. haloplanktis TAC 125 (Medigue et al., 2005). In depth sequencing by MALDI-MS and by de novo allowed to cover 14 additional sequence stretches (LYESEHATEFR, QQVIEAGR, TDVWNHPR, AGENLS, LVYTTW, VLDG-PL, WSLNPGYSV, LTSDLA-QPR, QPQFG-DR, YELF-QYSR, ELF-QYSR, VTPFVE_LLNSP, LF-A-TM-VGKK, ELETVL). Altogether, peptide sequencing of the Psc I-CgsA provided coverage of $23 \%$ of the 1060 amino acids of the P. haloplanktis Q3IKL4 protein (Figure 3). The sequence of the here described novel Psc l-CgsA was further confirmed as described in the following section.

\section{SEQUENCE DETERMINATION, CLONING AND OVEREXPRESSION OF THE ı-CgsA SULFATASE}

The nucleotide sequence encoding the Q3IKL4 protein without the peptide signal was used to design specific oligonucleotide primers that were used to clone and sequence the gene encoding the Psc $\iota-C g s A(\iota-c g s A)$ from $P$. carrageenovora. After successful expression and sequencing, the translation of the $\mathrm{l}-\operatorname{cgs} A$ gene yielded a protein of 1037 amino acids (GenBank accession number JN228253) with a theoretical isoelectric point (pI) value of 6.78 and a molecular weight of $115.9 \mathrm{kDa}$. This mass corresponds to the apparent molecular mass of the purified native and expressed Psc ı-CgsA $(\sim 110 \mathrm{kDa})$, deduced from SDS-PAGE. As expected, all the peptide sequences identified by mass spectrometry analysis were present in the protein sequence. The Psc l-CgsA shares $92.6 \%$ sequence identity with the putative uncharacterized protein Q3IKL4 of P. haloplanktis TAC 125 (Figure 3).

Psc ı-CgsA was expressed as a soluble protein at about $6.5 \mathrm{mg}$ $\mathrm{L}^{-1}$ in E. coli BL21 (DE3) when induced with $0.2 \%$ lactose
(ZYP 5052 medium). The yield was more than doubled (16.9 mg $\left.\mathrm{L}^{-1}\right)$ when induction was carried out with both lactose $(0.6 \%)$ and IPTG $(2 \mathrm{mM})$. After affinity chromatography on a HisPrep sepharose column, the enzyme was pure (Figure 2D). As shown on Figure 2D, the use of anti-histidine antibody allows recognizing the his-tagged protein which migrates as a single band at the expected size.

\section{BIOCHEMICAL CHARACTERIZATION OF THE NATIVE PsC I-CgsA PROTEIN}

The purified sulfatase was kinetically evaluated using carrageenan as substrates. The amount of sulfate released after incubation of the pure sulfatase using $\mathrm{l}-, \mathrm{\kappa}$ - or $\lambda$-carrageenan was monitored by HPAEC. In the presence of $\kappa$ - and $\lambda$-carrageenan, no desulfation was observed, even after prolonged incubation. In contrast, strong desulfation occurred when $\mathrm{l}$-carrageenan or hybrid $\mathrm{l}$-carrageenan containing about $20 \%$ of $\nu$-carrabiose was used as substrate, highlighting the specificity of this sulfatase toward the $\iota$-carrabiose moiety.

As shown in Figure 4, the desulfation reaction of ı-carrageenan by the Psc-ı sulfatase was slow, in the range of hours. The rate of sulfate release increased with the concentration of $\mathrm{l}$-carrageenan up to $0.6 \%(w / v)$. At higher concentrations the medium became very viscous interfering with the enzyme diffusion. When $0.5 \%(w / v)$ l-carrageenan was used, the rate of desulfation was linear for the first $15 \mathrm{~h}$. Under these experimental conditions the temperature optimum was determined to be 40 $\pm 5^{\circ} \mathrm{C}$ and the $\mathrm{pH}$ optimum was measured at 8.3 (Table 2). The Psc ı-CgsA could be kept for several months at $4^{\circ} \mathrm{C}$ at this $\mathrm{pH}$. Addition of sodium chloride at high concentrations affects the enzyme activity. Indeed, at $500 \mathrm{mM} \mathrm{NaCl}$, the activity drops to $17.5 \%$ of the optimal activity, observed at $200 \mathrm{mM} \mathrm{NaCl}$ (Table 2).

With the aim to determine the specificity of the $\mathrm{l}$-carrageenan sulfatase more precisely, the structural modification of 1 carrageenan was monitored, as a function of time, by ${ }^{1} \mathrm{H}$ NMR (Figure 4). The signals of ${ }^{1} \mathrm{H}$ NMR spectrum of the standard $\mathrm{l}$-carrageenan (Figure 4 top spectrum: $0 \mathrm{~h}$ ) were attributed on the basis of previously reported analyses (van de Velde et al., 2002). The signal observed at $5.32 \mathrm{ppm}$ corresponds 

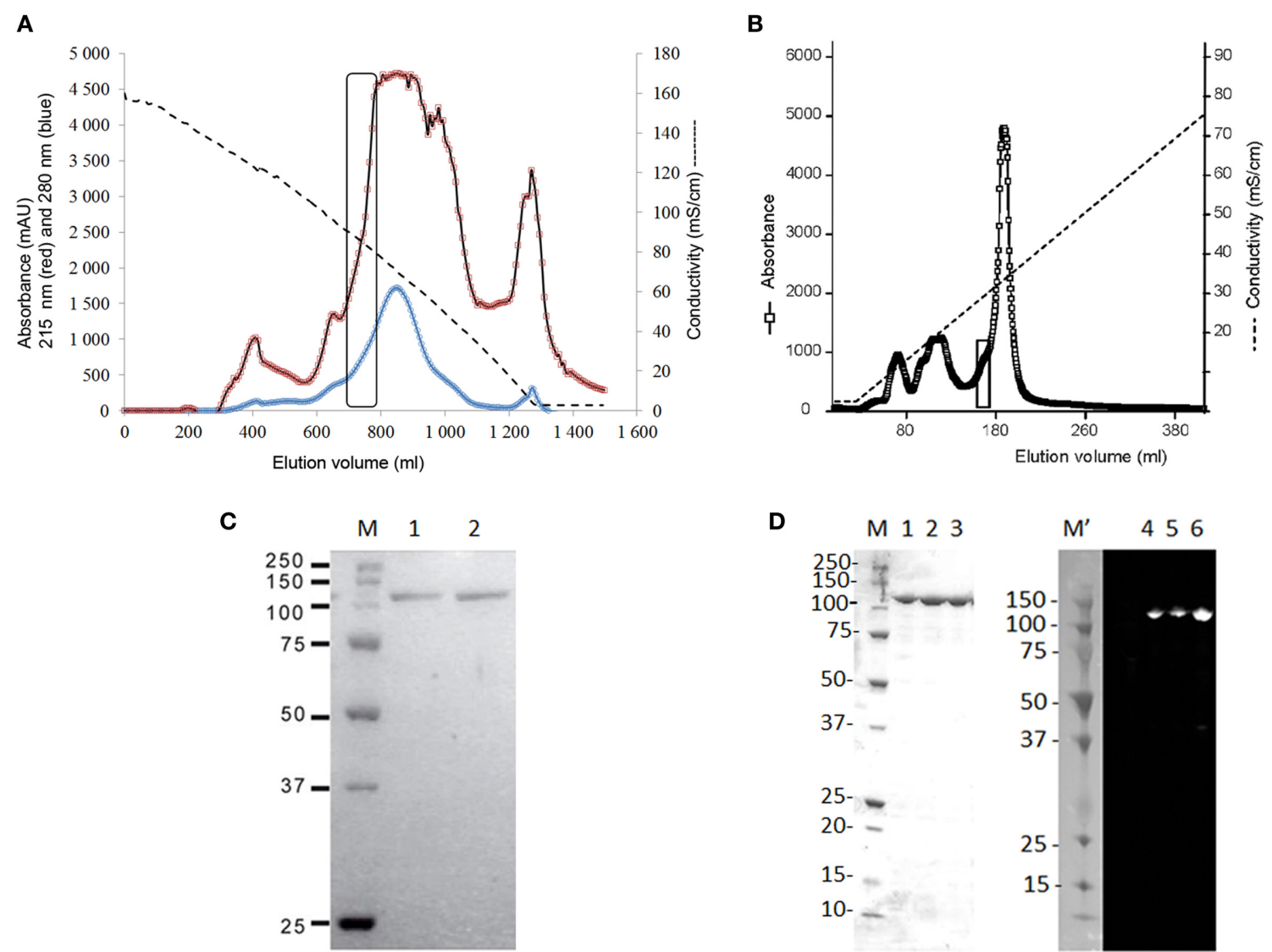

D
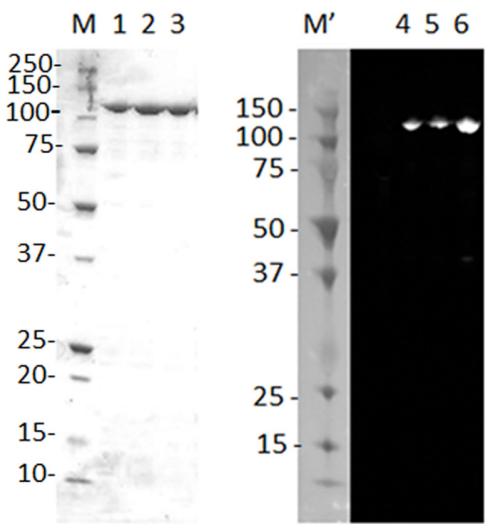

FIGURE 2 | Purification of the ı-carrageenan sulfatase. (A) Purification of the native $\mathrm{l}$-carrageenan sulfatase on a Phenyl Sepharose 6 fast flow high sub column $(2.0 \times 19.5 \mathrm{~cm})$. Elution of proteins was performed using a decreasing gradient from $30 \%$ saturation $\left(\mathrm{NH}_{4}\right)_{2} \mathrm{SO}_{4}$ in buffer $\mathrm{A}$ to $0 \%$ (dashed lines). The absorbance of the fractions $(6.5 \mathrm{ml})$ was measured both at $280 \mathrm{~nm}$ (blue curve) and at $215 \mathrm{~nm}$ (red curve). Active fractions containing sulfatase activity are surrounded with a rectangle. They were pooled and dialyzed against buffer $\mathrm{A}$ prior being loaded on top of the anion exchange chromatography, as described in material and methods. (B) Purification of the native t-carrageenan sulfatase on a DEAE-Sepharose fast flow column $(1.6 \times 13 \mathrm{~cm})$. Elution of proteins from the anion exchange chromatography was performed using an increasing gradient from 0 to $1 \mathrm{M} \mathrm{NaCl}$ (dashed line). The absorbance of the elution fractions was measured at $215 \mathrm{~nm}$ (open squares). Fractions containing pure PSC $\mathrm{l}-\mathrm{Cgs} \mathrm{A}$ are surrounded with a rectangle. (C) SDS- PAGE analysis of the native ı-carrageenan sulfatase isolated from $P$. carrageenovora. Elution fractions from the DEAE Sepharose chromatography were separated on $12 \%$ SDS-PAGE and stained with Colloïdal Coomassie Blue (Lanes 1-2). Precision protein standards from Bio-Rad were used as markers (Lane $M$, from top to bottom: $250 \mathrm{kDa}$, $150 \mathrm{kDa}, 100 \mathrm{kDa}, 75 \mathrm{kDa}, 50 \mathrm{kDa}, 37 \mathrm{kDa}$, and $25 \mathrm{kDa}$ ). (D) SDS- PAGE and Western Blot analysis of the recombinant his-tagged $\mathrm{l}$-carrageenan sulfatase after affinity chromatography. Lane M corresponds to the molecular weight markers (as above and in addition $20 \mathrm{kDa}, 15 \mathrm{kDa}$, and $10 \mathrm{kDa}$ ). Lanes 1 to 3: elution fractions from the HisPrep chromatography. Precision Plus protein dual color standards from BioRad were used as makers for the Western blot (Lane $\mathrm{M}^{\prime}$, sizes same as lane M). Lanes 4, 5, and 6 correspond to the Western blot analysis of the his-tagged sulfatase. Revelation was performed by chemiluminescence as described in material and methods. to the anomeric proton of the 4-linked anhydrogalactose unit (DA2S-H1). The G4S-H4 and DA2S-H3 protons, which signals are at $4.91 \mathrm{ppm}$ and $4.85 \mathrm{ppm}$ respectively, are also indicated on the spectrum. These signals decreased after $15 \mathrm{~h}$ of incubation of $41.25 \mathrm{mg}$ of l-carrageenan with $1.12 \mathrm{mg}$ of I-CgsA whilst two other signals, at $5.26 \mathrm{ppm}$ and $4.80 \mathrm{ppm}$, appeared (Figure 4, middle spectrum: $15 \mathrm{~h}$ ). To overcome heat inactivation of the enzyme, $300 \mu \mathrm{g}$ of Psc l-CgsA were added after $60 \mathrm{~h}$. This addition, combined with prolonged enzymatic incubation (up to $120 \mathrm{~h}$ ), allowed the complete modification of the l-carrageenan (Figure 4, bottom spectrum: 120 h). Based on the analyses reported by Falshaw et al. (1996), this spectrum is characteristic of alpha $(\alpha)$-carrageenan. Signals assignable to $\kappa-(5.1 \mathrm{ppm})$ or beta $(\beta)$-carrabiose units $(5.09 \mathrm{ppm})$ or to the production of reducing and non-reducing ends were not observed. This suggests that Psc ı-CgsA specifically catalyzes the conversion of $\iota$-carrabiose into $\alpha$-carrabiose units (Figure 1) within a polysaccharide chain and is devoid of glycoside hydrolase activity.

\section{BIOCHEMICAL CHARACTERIZATION OF THE RECOMBINANT I-CgsA PROTEIN}

The purified recombinant ı-CgsA was able to specifically remove sulfate from l-carrageenan. After $24 \mathrm{~h}$ of incubation at $35^{\circ} \mathrm{C}$ and $\mathrm{pH} 8.3$, the amount of sulfate released represents roughly $3 \%$ of the total sulfate of the polymer. Although this is not sufficient to detect the conversion of $\mathrm{l}$-carrageenan into $\alpha$-carrageenan by ${ }^{1} \mathrm{H}$ NMR, this low but significant activity confirmed that the 


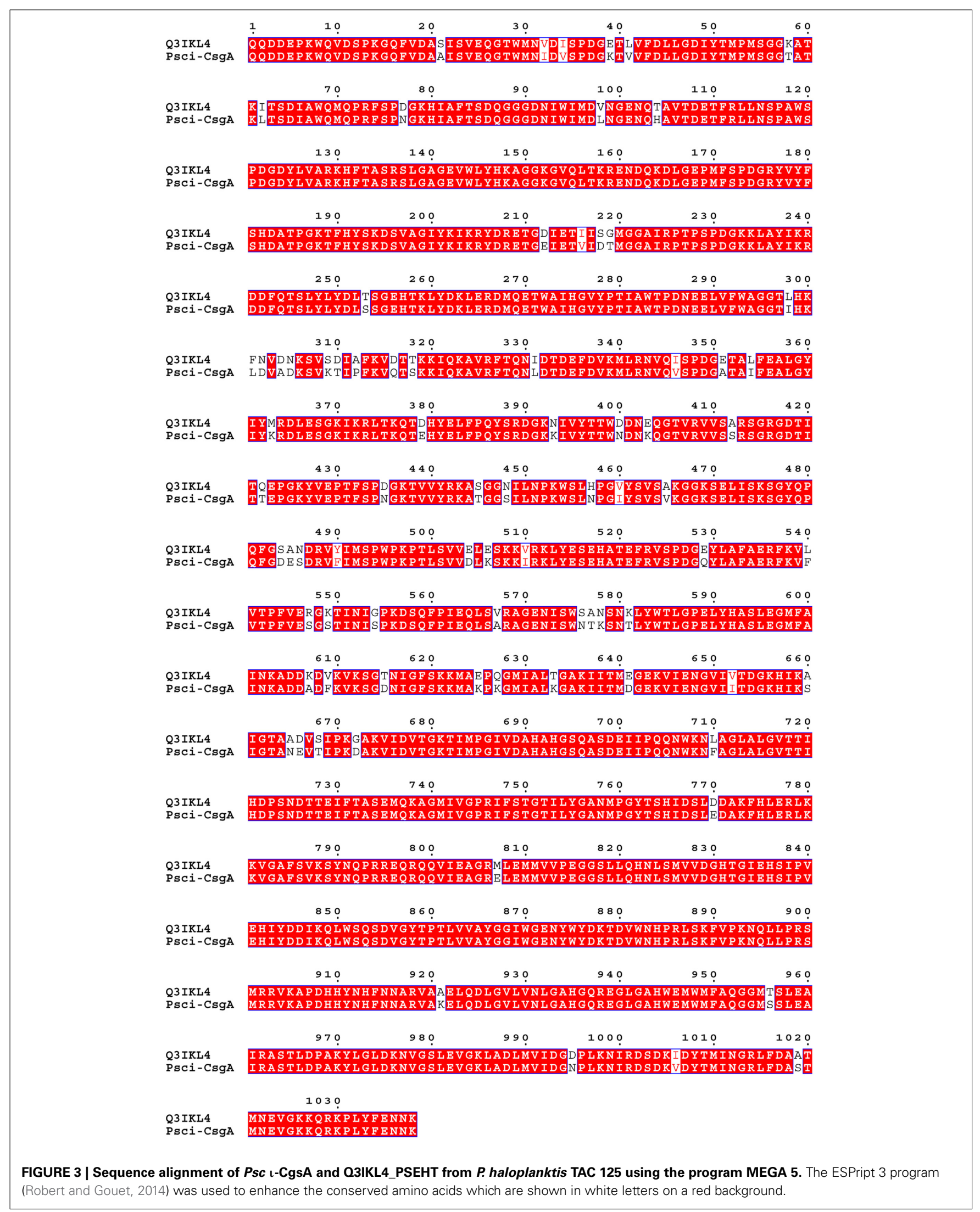


product of the cloned gene was a l-carrageenan sulfatase. As a consequence of the low activity, all further characterization of the recombinant enzyme was performed using an artificial substrate which is MUFS. As shown on Table $\mathbf{3 A}$, both native and recombinant enzymes are most active at $35^{\circ} \mathrm{C}$ and $\mathrm{pH}$ 8.3. Although the recombinant sulfatase shows an activity in MES comparable to that observed in the Tris buffer, its activity drops drastically in the 3-morpholinopropane-1-sulfonic acid (MOPS) buffer and in the phosphate/citrate buffer deviating from the trend of $\mathrm{pH}$ profile (data not shown). This therefore suggests that, in the case of the later buffer, inorganic phosphate may be an inhibitor of the ı-sulfatase.

The activity of the recombinant $\iota-C g s A$ was investigated in presence of different additives (Table $\mathbf{3 A}$ ), to be compared to the

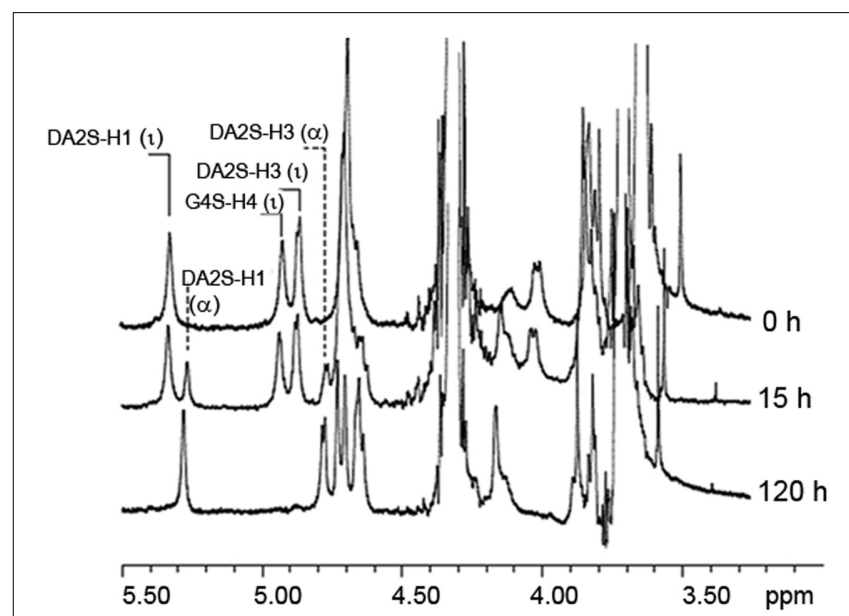

FIGURE 4 | ا-carrageenan desulfation with pure native ı-carrageenan sulfatase. ${ }^{1} \mathrm{HNMR}$ spectra monitoring the bioconversion of standard l-carrageenan (Top spectrum, $0 \mathrm{~h}$ ) into $\alpha$-carrageenan (Bottom spectrum). This conversion was performed after $120 \mathrm{~h}$ of incubation of $\mathrm{t}$-carrageenan with pure PSC I-CgsA (Bottom spectrum, 120h). Intermediate structures observed after $15 \mathrm{~h}$ of incubation (Middle spectrum, $15 \mathrm{~h}$ ), are hybrid เ- $/ \alpha$-carrageenans whose composition was deduced by integrating the $\alpha$-anomeric signal of DA2S-H1 ( 1 ) or $(\alpha)$ indicated on the spectra (Falshaw et al., 1996; van de Velde et al., 2002). native enzyme. Among them, $\mathrm{Mg}^{2+}$ and DTT inhibit slightly the enzyme whilst the addition of chelating agents such as EDTA an EGTA at $2 \mathrm{mM}$ does not affect the activity. EDTA has to be used at a concentration of $10 \mathrm{mM}$ to induce a slight decrease of the activity. The recombinant enzyme is completely inhibited when the concentration of $\mathrm{NaCl}$ reaches $500 \mathrm{mM}$. At $200 \mathrm{mM} \mathrm{NaCl}$, the recombinant enzyme has $89.6 \%$ of its optimal activity observed at $100 \mathrm{mM} \mathrm{NaCl}$.

The Michaelis parameters of both enzymes using an artificial substrate have been determined in optimal conditions using MUFS as substrate (Figure 5). These preliminary experiments show that while the $\mathrm{K}_{\mathrm{m}}$ of both enzymes are in the same order of magnitude, the kcat of the native enzyme is about 3 times that of the recombinant enzyme (Table 3B).

\section{DISCUSSION \\ DISCOVERY OF A I-CARRAGEENAN SULFATASE, ו-CgsA, SPECIFICALLY RELEASING SULFATE FROM THE D-GALACTOSE-4-SULFATE UNITS IN I-CARRAGEENAN}

Many genes encoding sulfatases have been cloned from all kingdoms of life (Sasaki et al., 1988; de Hostos et al., 1989; Paietta, 1989; Yang et al., 1989; Hallmann and Sumper, 1994; Ferrante et al., 2002; Medigue et al., 2005; Sardiello et al., 2005; Frese et al., 2008), but the number of characterized sulfatases remains limited and does not reflect the huge chemical diversity of sulfated biomolecules. The recent discovery that a vast number of sulfatases are present in marine bacteria (Glöckner et al., 2003; Barbeyron, personal communication) highlights the untapped resource of this type of activity in the marine environment. Indeed, most of the characterized sulfatases are specific of metabolizing glycosaminoglycans (Buono and Cosma, 2010), due to their importance in pathogenicity or human health. Nevertheless, it has been shown that the sulfatase from Sphingomonas sp. AS6330 (Kim et al., 2004) and the arylsufatase AtsA from P. carrageenovora $\mathrm{Psc}^{\mathrm{T}}$ (Lim et al., 2004; Kim et al., 2005) catalyze the desulfation of agar. Recently, a formylglycine-dependent endo-4S-ı-carrageenan sulfatase from the marine bacterium P. atlantica T6c has been purified and characterized (Préchoux et al., 2013). In the present study we have identified, sequenced

Table 2 | Biochemical characterization of the native Psc I-CgsA compared to two other polysaccharide sulfatases described in the literature.

\begin{tabular}{llll}
\hline Characteristics & Native Psc -CgsA & P. atlantica sulfatase & P. carrageenovora arylsulfatase \\
\hline Sulfatase family & New sulfatase family & Formylglycine family & $\beta$ - lactamase superfamily New sulfatase family \\
Polysaccharide substrate & t-carrageenan & -carrageenan & Agar \\
Molecular mass & $115.9 \mathrm{kDa}$ & $55.7 \mathrm{kDa}$ & $35.8 \mathrm{kDa}$ \\
Theoretical pl & 6.8 & 7.1 & 5.4 \\
Optimal temperature & $35-45^{\circ} \mathrm{C}$ & $35^{\circ} \mathrm{C}$ & $45^{\circ} \mathrm{C}$ \\
Optimal pH & 8.3 & 7.5 & $7.0-8.5$ \\
Optimal $\mathrm{NaCl]}$ & $200 \mathrm{mM}$ & $\sim 25 \mathrm{mM}$ & $\sim 500 \mathrm{mM}$ \\
EDTA $1 \mathrm{mM}$ & $0 \%$ inhibition & Data not available & $53.2 \%$ inhibition \\
PMSF 1 mM & $91 \%$ inhibition & Data not available & $26 \%$ inhibition \\
Phosphate buffer & $82 \%$ inhibition & Data not available & Inhibition
\end{tabular}

Both the native PSC ı-CgsA and the ı-carrageenan sulfatase from P. atlantica (Préchoux et al., 2013) were characterized using ı-carrageenan as substrate. The data are compared to those of the arylsulfatase isolated from P. carrageenovora (Barbeyron et al., 1995; Lim et al., 2004; Kim et al., 2005). 
and characterized a novel $\iota$-carrageenan sulfatase, Psc ı-CgsA, first member of a new family of sulfatases. NMR studies of the reaction products unambiguously demonstrate that Psc lCgsA catalyzes the removal of the sulfate ester group localized on the position $\mathrm{C} 4$ of the G4S moieties from the $\mathrm{l}$-carrabiose units, leading to the formation of $\alpha$-carrabiose units. Despite the complete absence of sequence homology, this activity appears to be the same as that already described for the formylglycinedependent sulfatase from the marine bacterium $P$. atlantica T6c, indicating that this catabolic activity plays an important role in carrageenan metabolization.The desulfation is $\iota$-carrageenan specific, since neither the $P$. atlantica $4 \mathrm{~S}$-ı-carrageenan sulfatase nor the here described Psc ı-CgsA sulfatase are able to catalyze the removal of the $4 \mathrm{~S}$ sulfate group from $\kappa$-carrabiose units. In $\kappa$-carrageenan, the G4S residues are located between two neutral anhydrogalactose residues whilst in l-carrageenan the G4S moieties are positioned between two sulfated anhydrogalactose residues (Figure 1). This finding therefore allows the assumption that the substrate specificity in these endo-sulfatases includes the recognition of at least one additional sulfated anhydrogalactose in their substrate binding site to display the observed specificity.

Table 3 | Characterization of the native and the recombinant Psc ı-CgsA.

\section{(A) BIOCHEMICAL CHARACTERIZATION}

\section{Characteristics}

Optimal temperature $\left({ }^{\circ} \mathrm{C}\right)$

Optimal pH

Optimal $[\mathrm{NaCl}](\mathrm{mM})$

EDTA $10 \mathrm{mM}$

EGTA $10 \mathrm{mM}$

$\mathrm{MgCl}_{2}$ up to $2 \mathrm{mM}$

DTT $1 \mathrm{mM}$

PMSF 2 mM
Native Psc ı-CgsA Recombinant Psc ı-CgsA

$35-45$
8.3

200

$132.8 \% \pm 12.9$

$125.5 \% \pm 9.2$

$37.8 \% \pm 2.8$

$46.8 \% \pm 4.2$

$0 \%$
35

$8.4 \pm 0.3$

100

$93.6 \% \pm 3.3$

$100.9 \% \pm 8.5$

$81.7 \% \pm 2.5$

$74.8 \% \pm 6.9$

$34.1 \% \pm 13.4$
Characterization of the native enzyme has been performed using $\iota$-carrageenan whereas MUFS was used for the recombinant enzyme. As stated in material and methods, incubation with $\mathrm{l}$-carrageenan was performed during $12 \mathrm{~h}$ whilst kinetics with MUFS were carried out for $2 \mathrm{~h}$. Unless otherwise stated, the activity is expressed as the percentage of the initial activity observed without addition of reagents.

\section{(B) KINETIC PARAMETERS}

\begin{tabular}{lccc} 
Enzyme & $\begin{array}{c}\text { Apparent } \\
\text { Km }(\boldsymbol{\mu} \mathbf{M})\end{array}$ & $\begin{array}{c}\boldsymbol{k c a t} \\
\left(\mathbf{m i n}^{-\mathbf{1}}\right)\end{array}$ & $\begin{array}{c}\text { Kcat/Km } \\
\left(\boldsymbol{\mu} \mathbf{M}^{-\mathbf{1}} \mathbf{~ m i n}^{\mathbf{1}}\right)\end{array}$ \\
\hline Native PsC ı-CgsA & $21.9 \pm 8.2$ & $6.32 \pm 0.38$ & $0.280 \pm 0.05$ \\
Recombinant ı-CgsA & $13.4 \pm 4.9$ & $1.64 \pm 0.23$ & $0.12 \pm 0.04$ \\
Arylsulfatase from & 68 & $\mathrm{ND}$ & $\mathrm{ND}$ \\
$P$ carrageenovora & & &
\end{tabular}

Preliminary kinetic parameters of the native and recombinant PSC ı-CgsA were measured using the optimal reaction conditions of the enzymes as determined above and the artificial substrate MUFS at concentrations ranging from 5.2 to $206.5 \mu \mathrm{M}$. Data are compared to that of the P. carrageenovora arylsulfatase (Barbeyron et al., 1995) using the same substrate. N.D. means not determined.

\section{THE I-CARRAGEENAN SULFATASE I-CgsA IS A MODULAR ENZYME BELONGING TO A NOVEL CLASS OF SULFATASES}

Despite their identical substrate specificity, the l-carrageenan sulfatases of $P$. carrageenovora $\mathrm{Psc}^{\mathrm{T}}$ and $P$. atlantica T6c have very different biochemical characteristics (Table 2) and can also be distinguished by their primary sequence that do not share enough similarity to allow an accurate sequence alignment. The $\mathrm{l}$-carrageennan sulfatase from $P$. atlantica T6c is indeed a formylglycine sulfatase and in this respect it has the characteristic signatures of family 1 formylglycine-dependent sulfatases, namely [SAPG]-[LIVMST]-[CS]-[STACG]-P-[STA]-R-x(2)[LIVMFW](2)-[TAR]-G and G-[YV]-x-[ST]-x(2)-[IVAS]-G$\mathrm{K}-\mathrm{x}(0,1)-[\mathrm{FYWMK}]-[\mathrm{HL}]$ (Prosite signatures PS00523 and PS00149 respectively), which are well conserved in this family of enzymes. These signatures are not present in the Psc l-CgsA sulfatase, thus indicating that this latter enzyme does not belong to the well-defined and represented family of formylglycine-dependent sulfatases. Sequence alignment of the Psc-ı sulfatase with the protein Q3IKL4 from $P$. haloplanktis and 9 other proteins chosen amongst the ones representing the new sulfatase family revealed that no cystein amino acids are conserved (Supplementary Figure 1). However, several conserved serine could potentially be subjected to post-translational modification. Therefore, and based on sequence data alone, it cannot be completely excluded (although improbable) that this sulfatase potentially reveals the existence of a new formylglycine-dependent family. It would however involve a serine modification. Interestingly, a $\mathrm{l}$-carrageenan sulfatase was revealed to be very active in $P$. haloplanktis $545^{\mathrm{T}}$ extracts. This enzyme was induced in similar conditions to those observed for induction of the Psc l-CgsA (Table 1, data in brackets). Since the genomes of both sequenced strains of $P$. haloplanktis TAC 125 (Medigue et al., 2005) and P. haloplanktis ANT/505 (GenBank ADOP00000000.1) do not contain any formylglycine-dependent sulfatase genes, it is tempting to assume that the sulfatase activity detected in P. haloplanktis $545^{\mathrm{T}}$ is due to a l-CgsA-type enzyme, such as in $P$. carrageenovora. Indeed, as described above, proteins orthologous to Psc ı-CgsA are present both in P. haloplanktis TAC 125 and ANT/505.

A BlastP sequence similarity search with the Psc l-CgsA used as query sequence against the Uniprot database revealed that $P s c$ lCgsA showed more than $90 \%$ identity with putative uncharacterized proteins from several marine species of Pseudoalteromonas. Moreover, many proteins from different marine strains such as Colwellia psychrerythraea 34H (Methe et al., 2005) and Shewanella sediminis HAW-EB3, belonging to the amidohydrolase superfamily, exhibited more than $60 \%$ of identity with the Psc l-CgsA sulfatase (Supplementary Figure 1). Three-dimensional structure modeling of Psc ı-CgsA using the Phyre2 (Kelley and Sternberg, 2009) tool reveals that Psc ı-CgsA most likely has a multi-modular arrangement that covers $94 \%$ of the residues and are modeled with more than $90 \%$ of confidence. From this model it is hypothesized that Psc $\mathrm{l}$-CgsA consists of an N-terminal module (from residues 24 to 618 approximately) featuring a first $\beta$-propeller fold composed of six blades (from residues 24 to 300 approximately), and a second $\beta$-propeller fold composed of seven blades (from residues 310 to 618 approximately). This type of organization has already been observed among carbohydrate processing 


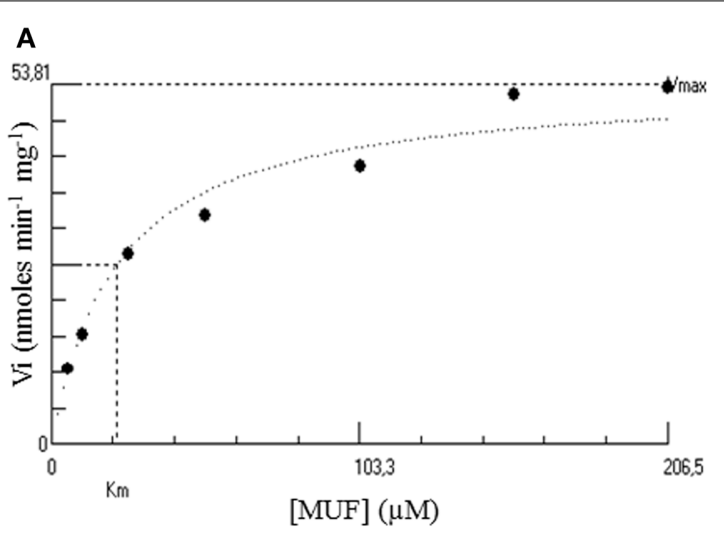

FIGURE 5 | Hyperbolic regression determination of the kinetic parameters of both the native (A) and the His-tagged (B) Psc I-CgsA. Kinetics were performed at $35^{\circ} \mathrm{C}$ using MUFS at different concentrations

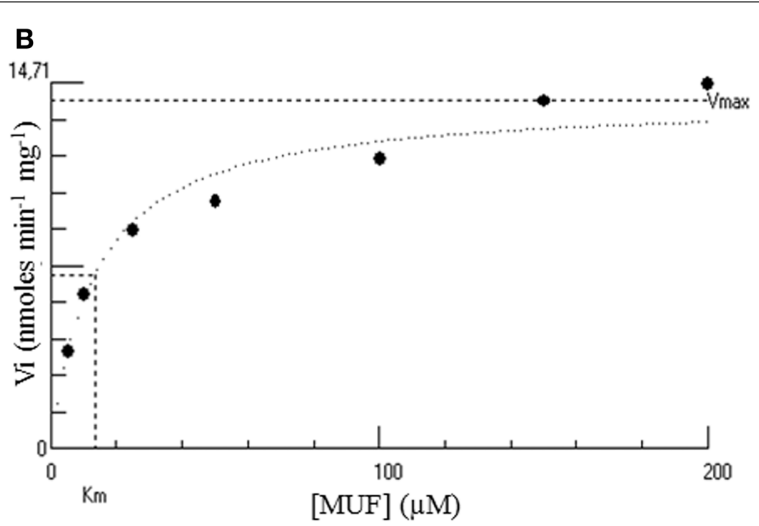

from 5.2 to $206.5 \mu \mathrm{M}$. These plots have been performed using the software Hyper32 version 1.0.0. (http://homepage.ntlworld.com/john.easterby). They are representative of experiments performed in triplicates. enzymes, such as glycoside hydrolases from the clans GHE, GHF, $\mathrm{GHJ}$, and for $\lambda$-carrageenases (Guibet et al., 2007), but also in the PL11 family of polysaccharide lyases involved in the degradation of anionic polysaccharides. The C-terminal module (comprising amino acids 663-1060 in Psc ı-CgsA) displays a typical TIM-barrel fold found in the amidohydrolase superfamily. This superfamily includes an outstanding set of enzymes that catalyze the hydrolysis of a wide range of substrate having amide or ester groups. For example, urease, amidohydrolase, guanine deaminases and phosphoesterase share the same three-dimensional fold describing this superfamily (Seibert and Raushel, 2005).

A phylogenetic analysis of the C-terminal module found in Psc ı-CgsA and in 420 sequences of enzymes classified as belonging to the amidohydrolases superfamily showed that Psc l-CgsA was not related to any known activity in this superfamily (Figure 6). In contrast, it appears that Psc ı-CgsA belongs to a clade composed of uncharacterized proteins only. In this cluster, a sub-clade supported by a node with a relatively good bootstrap value $(73 \%)$ is composed of 122 sequences displaying the same modular organization as Psc ı-CgsA (i.e., the presence of $\beta$-propeller modules at the N-terminal extremity) (Supplementary Table 1). The topology of the phylogenetic tree suggests that Psc l-CgsA and these 122 sequences represent a novel family of sulfatases, which might have different substrate specificities, as supported by the low percentage of sequence identity between some proteins within this clade.

\section{PRODUCTION AND ANALYSIS OF THE RECOMBINANT I-CARRAGEENAN SULFATASE}

In addition to the identification of the native Psc l-CgsA enzyme, the gene coding for Psc l-CgsA was successfully cloned and heterologously expressed in E. coli, although the purified recombinant enzyme displayed lower activity on the natural substrate than the native form. The biochemical characteristics of the native and the recombinant enzymes, measured on the artificial substrate MUFS, are very similar (Table 3A), but the kcat of the native enzyme is roughly about 3 times that of the recombinant enzyme (Table 3B). The slightly different biochemical behavior of native vs. recombinant enzyme might be due to intrinsic elements in the native protein that $E$. coli does not supply, such as potential post-translational modifications and/or the requirement of a cofactor or a chaperone during protein folding, preventing the production of a fully active recombinant enzyme. Future work and a more detailed biochemical depiction of different recombinant homologs of this novel sulfatase family are necessary, and will shed more light on the precise catalytic mechanism and mode of action of this newly discovered enzyme family.

\section{DECIPHERING A NEW PATHWAY FOR CARRAGEENAN BIODEGRADATION}

The degradation pathway of $\kappa$-carrageenan by $P$. carrageenovora $\mathrm{Psc}^{\mathrm{T}}$ has been partially determined and involves a $\kappa$-carrageenase (Weigl and Yaphe, 1966a; McLean and Williamson, 1979a; Barbeyron et al., 1994; Michel et al., 2001) to produce oligosaccharides which are readily degraded into neocarrabiose through the concerted action of a glycosulfatase (Weigl and Yaphe, 1966b; McLean and Williamson, 1979b) and a neocarratetraose monosulfate hydrolase (McLean and Williamson, 1981). For the catabolism of $\mathrm{l}$-carrageenan a similar pathway might be assumed as a low $\mathrm{l}$-carrageenase activity has been detected in the crude extract of $P$. carrageenovora Psc $^{\mathrm{T}}$ (Henares et al., 2010). However, based on our results with Psc l-CgsA, we propose an alternative mechanism in which $\mathrm{l}$-carrageenan is first desulfated and converted into $\alpha$-carrageenan. The latter likely constitutes a metabolic intermediate probably subject to further degradation by an $\alpha$-carrageenase and/or desulfation by other sulfatases, leading to the end-product of galactose residues. Except for the conversion of $\mathrm{l}$ - into $\alpha$-carrageenan, these steps are speculative and need to be corroborated.

\section{BIOCONVERSION OF RED ALGAL POLYSACCHARIDES}

$\alpha$-Carrageenan has been observed in the cell wall of several red algae such as Catenella nipae Zanardini (Zablackis and Santos, 1986), Sarconema filiforme (Sonder) Kylin (Chiovitti et al., 1998; Kumar et al., 2011) and in some Solieria spp. (Chiovitti et al., 1997; Bondu et al., 2010). Although structural studies revealed 


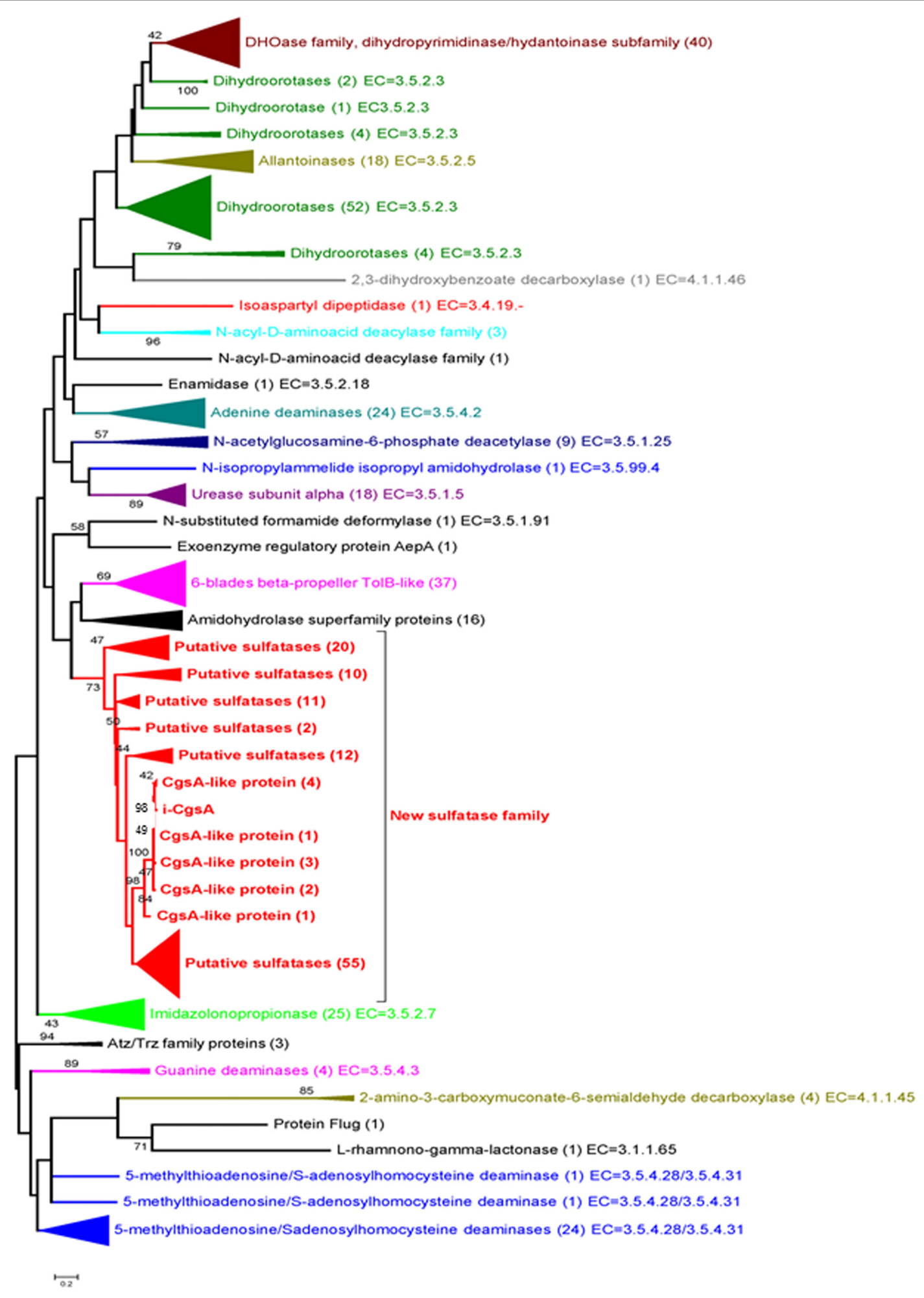

FIGURE 6 | Phylogenetic tree of the amidohydrolase module present in Psc $\mathrm{L}-$ Cgs $A$ and in $\mathbf{4 2 0}$ sequences of enzymes classified as amidohydrolases. The maximum likelihood tree was built with the MEGA v. 5.05. Software, using the substitution model WAG. Evolutionary rate differences among sites (5 categories) were modeled using a discrete Gamma distribution, from an alignment produced by the MAFFT program with the L-INSi algorithm (Katoh et al., 2005). Phylogenetic analysis was performed using 171 positions, defined from the multiple sequence alignment. All ambiguous positions were removed for each sequence pair. Only the bootstrap values higher than 40 are shown. The potential new sulfatase family (in red) was delimited on the basis of sequence similarities to the here identified sulfatase and the bootstrap value (73) of the best node (the deepest, the first red node) in the tree. Numbers in brackets indicate the number of sequences involved in each group. 
that this carrageenan referred to as hybrids of $\alpha$-/l-carrageenan in which the $\alpha$-carrabiose content does not exceed $30-40 \%$ ( $\mathrm{mol} / \mathrm{mol}$ ) (Falshaw et al., 1996), it has been shown that the sodium salt of such hybrids exhibit twice the capacity to suspend cacao particles in milk compared to $\kappa$-carrageenan which is commonly used for that purpose (Zablackis and Santos, 1986). As suggested by Figure 4, the Psc-l-CgsA sulfatase could be used to produce carrageenan with controlled ratio of $\mathrm{\imath}-/ \alpha$-carrabiose and even pure $\alpha$-carrageenan. It is therefore more than likely that new hybrids of $\alpha$-/l-carrageenans or pure $\alpha$-carrageenan will harbor new and interesting functional properties.

Recent marine genomic projects have shown that marine bacteria are a potential source of large sulfatase diversity, with the presence of huge multigenic sulfatase families, as exemplified by the formylglycine-dependent sulfatase family (up to 300 genes in the Lentisphaera araneosa HTCC $2155^{\mathrm{T}}$ genome) (Thrash et al., 2010). Since the origin of these bacteria is marine, it is tempting to assume that a large portion of these enzymes are involved in the degradation of sulfated polysaccharides from marine algae (Glöckner et al., 2003). In addition to these sulfatases accessible through genome mining, our work demonstrates that the sulfatase diversity extends even beyond those that have already characterized members. By screening a marine bacterium for sulfatase activity on carrageenan substrate, we have successfully identified and characterized a new sulfatase family, members of which were annotated "hypothetical proteins with unknown function" before hand. Altogether, these data open up a large field for future work, necessitating substantial experimental effort to provide all the biochemical details to assign precise substrate specificities to these newly identified sulfatases. The immediate gain of such efforts will be a large panel of new marine polysaccharide sulfatases that represent interesting enzymatic tools to fine-tune the physico-chemical properties of algal polysaccharides.

\section{ACKNOWLEDGMENTS}

We thank Audrey Geairon for excellent technical assistance in mass spectrometry analyses. Special thanks also to Nelly Kervarec and Morgan Perennou for NMR analysis and DNA sequencing respectively. We also thank Dr. Fanny Gaillard for her help with the mass spectrometry analyses, Dr. Thierry Tonon, Dr. Simon Dittami and Dr. Mirjam Czjzek for critical reading of the manuscript. This work has received funding from the European Community's Seventh Framework Program (FP7/2007-2013) under grant agreement No. 222628 (Large collaborative project PolyModE, http://www.polymode.eu/).

\section{SUPPLEMENTARY MATERIAL}

The Supplementary Material for this article can be found online at: http://www.frontiersin.org/journal/10.3389/fchem. 2014.00067/abstract

\section{REFERENCES}

Altschul, S. F., Madden, T. L., Schaffer, A. A., Zhang, J., Zhang, Z., Miller, W., et al. (1997). Gapped BLAST and PSI-BLAST: a new generation of protein database search programs. Nucleic Acids Res. 25, 3389-3402. doi: 10.1093/nar/25.17.3389

Barbeyron, T., Henrissat, B., and Kloareg, B. (1994). The gene encoding the kappa-carrageenase of Alteromonas carrageenovora is related to beta-1,3-1,4glucanases. Gene 139, 105-109. doi: 10.1016/0378-1119(94)90531-2
Barbeyron, T., Kean, K., and Forterre, P. (1984). DNA adenine methylation of GATC sequences appeared recently in the Escherichia coli lineage. J. Bacteriol. 160, 586-590.

Barbeyron, T., Potin, P., Richard, C., Collin, O., and Kloareg, B. (1995). Arylsulphatase from Alteromonas carrageenovora. Microbiology 141, 2897-2904. doi: 10.1099/13500872-141-11-2897

Bellion, C., Hamer, G. K., and Yaphe, W. (1982). The degradation of Eucheuma spinosum and Eucheuma cottonii carrageenans by $\mathrm{l}$-carrageenases and $\mathrm{\kappa}$ carrageenases from marine bacteria. Can. J. Microbiol. 28, 874-880. doi: $10.1139 / \mathrm{m} 82-129$

Bendtsen, J. D., Nielsen, H., von Heijne, G., and Brunak, S. (2004). Improved prediction of signal peptides: signalp 3.0. J. Mol. Biol. 340, 783-795. doi: 10.1016/j.jmb.2004.05.028

Bondu, S., Deslandes, E., Fabre, M., Berthou, C., and Guangli, Y. (2010). Carrageenan from Solieria chordalis (Gigartinales): structural analysis and immunological activities of the low molecular weight fractions. Carbohydr. Polym. 81, 448-460. doi: 10.1016/j.carbpol.2010.02.046

Bradford, M. M. (1976). A rapid and sensitive method for the quantitation of microgram quantities of protein utilizing the principle of protein-dye binding. Anal. Biochem. 72, 248-254. doi: 10.1016/0003-2697(76)90527-3

Buono, M., and Cosma, M. P. (2010). Sulfatase activities towards the regulation of cell metabolism and signaling in mammals. Cell. Mol. Life Sci. 67, 769-780. doi: 10.1007/s00018-009-0203-3

Candiano, G., Bruschi, M., Musante, L., Santucci, L., Ghiggeri, G. M., Carnemolla, B., et al. (2004). Blue silver: a very sensitive colloidal Coomassie G250 staining for proteome analysis. Electrophoresis 25, 1327-1333. doi: 10.1002/elps.200305844

Chiovitti, A., Bacic, A., Craik, D. J., Munro, S. L., Kraft, G. T., and Liao, M. (1997). Cell-wall polysaccharides from Australian red algae of the family Solieriaceae (Gigartinales, Rhodophyta): novel, highly pyruvated carrageenans from the genus Callophycus. Carbohydr. Res. 299, 229-243. doi: 10.1016/S00086215(97)00017-7

Chiovitti, A., Bacic, A., Craik, D., Kraft, G. T., Liao, M., Falshaw, R., et al. (1998). A pyruvated carrageenan from Australian specimens of the red alga Sarconema filiforme. Carbohydr. Res. 310, 77-83. doi: 10.1016/S0008-6215(98) 00170-0

de Hostos, E. L., Schilling, J., and Grossman, A. R. (1989). Structure and expression of the gene encoding the periplasmic arylsulfatase of Chlamydomonas reinhardtii. Mol. Gen. Genet. 218, 229-239. doi: 10.1007/BF00331273

de Ruiter, G. A., and Rudolph, B. (1997). Carrageenan biotechnology. Trends Food Sci. Technol. 8, 389-395. doi: 10.1016/S0924-2244(97)01091-1

Ekborg, N. A., Taylor, L. E., Longmire, A. G., Henrissat, B., Weiner, R. M., and Hutcheson, S. W. (2006). Genomic and proteomic analyses of the agarolytic system expressed by Saccharophagus degradans 2-40. Appl. Environ. Microbiol. 72, 3396-3405. doi: 10.1128/AEM.72.5.3396-3405.2006

Falshaw, R., Furneaux, R. H., Wong, H., Liao, M., Bacic, A., and Chandrkrachang, S. (1996). Structural analysis of carrageenans from Burmese and Thai samples of Catenella nipae Zanardini. Carbohydr. Res. 285, 81-98. doi: 10.1016/S00086215(96)90174-3

Ferrante, P., Messali, S., Meroni, G., and Ballabio, A. (2002). Molecular and biochemical characterisation of a novel sulphatase gene: arylsulfatase G (ARSG). Eur. J. Hum. Genet. 10, 813-818. doi: 10.1038/sj.ejhg.5200887

Frese, M. A., Schulz, S., and Dierks, T. (2008). Arylsulfatase G, a novel lysosomal sulfatase. J. Biol. Chem. 283, 11388-11395. doi: 10.1074/jbc.M7099 17200

Genicot-Joncour, S., Poinas, A., Richard, O., Potin, P., Rudolph, B., Kloareg, B., et al. (2009). The cyclization of the 3,6-anhydro-galactose ring of iota-carrageenan is catalyzed by two D-galactose-2,6-sulfurylases in the red alga Chondrus crispus. Plant Physiol. 151, 1609-1616. doi: 10.1104/pp.109.144329

Glöckner, F. O., Kube, M., Bauer, M., Teeling, H., Lombardot, T., Ludwig, W., et al. (2003). Complete genome sequence of the marine planctomycete Pirellula sp. strain 1. PNAS 100, 8298-8303. doi: 10.1073/pnas.1431443100

Groisillier, A., Hervé, C., Jeudy, A., Rebuffet, E., Pluchon, P. F., Chevolot, Y., et al. (2010). MARINE-EXPRESS: taking advantage of high throughput cloning and expression strategies for the post-genomic analysis of marine organisms. Microb. Cell. Fact. 9, 45-55. doi: 10.1186/1475-2859-9-45

Guibet, M., Colin, S., Barbeyron, T., Genicot, S., Kloareg, B., Michel, G., et al. (2007). Degradation of lambda-carrageenan by Pseudoalteromonas carrageenovora lambda-carrageenase: a new family of glycoside hydrolases 
unrelated to kappa- and iota-carrageenases. Biochem. J. 404, 105-114. doi: 10.1042/BJ20061359

Hallmann, A., and Sumper, M. (1994). An inducible arylsulfatase of Volvox carteri with properties suitable for a reporter-gene system. Purification, characterization and molecular cloning. Eur. J. Biochem. 221, 143-150. doi: 10.1111/j.14321033.1994.tb18723.x

Henares, B. M., Enriquez, E. P., Dayrit, F. M., and Rojas, N. R. (2010). Iota-carrageenan hydrolysis by Pseudoalteromonas carrageenovora IFO 12985. Phil. J. Sci. 139, 131-138. Available online at: http://philjournalsci.dost. gov.ph/vol139no2/pdfs/Iota\%20carrageenan\%20hydrolysis.pdf

Katoh, K., Kuma, K., Toh, H., and Miyata, T. (2005). MAFFT version 5: improvement in accuracy of multiple sequence alignment. Nucleic Acids Res. 33, 511-518. doi: 10.1093/nar/gki198

Kelley, L. A., and Sternberg, M. J. (2009). Protein structure prediction on the Web: a case study using the Phyre server. Nat. Protoc. 4, 363-371. doi: 10.1038/nprot.2009.2

Kennedy, J., Marchesi, J. R., and Dobson, A. D. W. (2008). Marine metagenomics strategies for discovery of novel enzymes with biotechnological applications from marine ecosystems. Microb. Cell Fact. 7:27. doi: 10.1186/14752859-7-27

Kim, D. E., Kim, K. H., Bae, Y. J., Lee, J. H., Jang, Y. H., and Nam, S. W. (2005). Purification and characterization of the recombinant arylsulfatase cloned from Pseudoalteromonas carrageenovora. Prot. Expr. Purif. 39, 107-115. doi: 10.1016/j.pep.2004.09.007

Kim, J. H., Byun, D. S., Godber, J. S., Choi, J. S., Choi, W. C., and Kim, H. R. (2004). Purification and characterization of arylsulfatase from Sphingomonas sp. AS6330. Appl. Microbiol. Biotechnol. 63, 553-559. doi: 10.1007/s00253-0031463-8

Kloareg, B., and Quatrano, R. S. (1988). Structure of the cell-walls of marine-algae and ecophysiological functions of the matrix polysaccharides. Oceanogr. Mar. Biol. 26, 259-315.

Knutsen, S., Myslabodski, D., Larsen, B., and Usov, A. (1994). A modified system of nomenclature for red algal galactans. Bot. Mar. 37, 163-169. doi: 10.1515/botm.1994.37.2.163

Korf, U., Kohl, T., van der Zandt, H., Zahn, R., Schleeger, S., Ueberle, B., et al. (2005). Large-scale protein expression for proteome research. Proteomics 5, 3571-3580. doi: 10.1002/pmic.200401195

Kumar, S., Mehta, G. K., Prasad, K., Meena, R., and Siddhanta, A. K. (2011). Chemical investigation of carrageenan from the red alga Sarconema filiforme (Gigartinales, Rhodophyta) of Indian waters. Nat. Prod. Commun. 6, 1327-1332.

Laemmli, U. K., and Favre, H. (1973). Maturation of the head of bacteriophage T4. I DNA packaging events. J. Biol. Chem. 80, 575-599.

Lahaye, M., and Robic, A. (2007). Structure and functional properties of ulvan, a polysaccharide from green seaweeds. Biomacromolecules 8, 1765-1774. doi: 10.1021/bm061185q

Larré, C., Penninck, S., Bouchet, B., Lollier, V., Tranquet, O., Denery-Papini, S., et al. (2010). Brachypodium distachyon grain: identification and subcellular localization of storage proteins. J. Exp. Bot. 61, 1771-1783. doi: 10.1093/jxb/erq050

Lim, J. M., Jang, Y. H., Kim, H. R., Kim, Y. T., Choi, T. J., Kim, J. K., et al. (2004). Overexpression of arylsulfatase in E. coli and its application to desulfatation of agar. J. Microbiol. Biotechn. 14, 777-782. Available online at: http://www.jmb.or.kr/

McLean, M. W., and Williamson, F. B. (1979a). Glycosulphatase from Pseudomonas carrageenovora. Purification and some properties. Eur. J. Biochem. 101, 497-505. doi: 10.1111/j.1432-1033.1979.tb19744.x

McLean, M. W., and Williamson, F. B. (1979b). Kappa-Carrageenase from Pseudomonas carrageenovora. Eur. J. Biochem. 93, 553-558. doi: 10.1111/j.14321033.1979.tb12854.x

McLean, M. W., and Williamson, F. B. (1981). Neocarratetraose 4-O-monosulphate beta-hydrolase from Pseudomonas carrageenovora. Eur. J. Biochem. 113, 447-456. doi: 10.1111/j.1432-1033.1981.tb05084.x

Medigue, C., Krin, E., Pascal, G., Barbe, V., Bernsel, A., Bertin, P. N., et al. (2005). Coping with cold: the genome of the versatile marine Antarctica bacterium Pseudoalteromonas haloplanktis TAC125. Genome Res. 15, 1325-1335. doi: $10.1101 /$ gr.4126905

Methe, B. A., Nelson, K. E., Deming, J. W., Momen, B., Melamud, E., Zhang, X., et al. (2005). The psychrophilic lifestyle as revealed by the genome sequence of
Colwellia psychrerythraea $34 \mathrm{H}$ through genomic and proteomic analyses. Proc. Natl. Acad. Sci. U.S.A. 102, 10913-10918. doi: 10.1073/pnas.0504766102

Michel, G., Chantalat, L., Duee, E., Barbeyron, T., Henrissat, B., Kloareg, B., et al. (2001). The kappa-carrageenase of $P$. carrageenovora features a tunnel-shaped active site: a novel insight in the evolution of Clan-B glycoside hydrolases. Structure 9, 513-525. doi: 10.1016/S0969-2126(01)00612-8

Michel, G., Nyval-Collen, P., Barbeyron, T., Czjzek, M., and Helbert, W. (2006). Bioconversion of red seaweed galactans: a focus on bacterial agarases and carrageenases. Appl. Microbiol. Biotechnol. 71, 23-33. doi: 10.1007/s00253-0060377-7

Michel, G., Tonon, T., Scornet, D., Cock, J. M., and and Kloareg, B. (2010). The cell wall polysaccharide metabolism of the brown alga Ectocarpus siliculosus. Insights into the evolution of extracellular matrix polysaccharides in Eukaryotes. New Phytol. 188, 82-97. doi: 10.1111/j.1469-8137.2010.03374.x

Necas, J., and Bartosikova, L. (2013). Carrageenan: a review. Vet. Med. 58, 187-205. Available online at: http://www.vri.cz/docs/vetmed/58-4-187.pdf

Paietta, J. V. (1989). Molecular cloning and regulatory analysis of the arylsulfatase structural gene of Neurospora crassa. Mol. Cell. Biol. 9, 3630-3637.

Pereira, L., Crichley, A. T., Amado, A. M., and Ribeiro-Claro, P. J. A. (2009). A comparative analysis of phycocolloids produced by underutilized versus industrially utilized carrageenophytes (Gigartinales, Rhodophyta). J. Appl. Phycol. 21, 599-605. doi: 10.1007/s10811-009-9447-4

Pereira, L., and Mesquita, J. (2004). Population studies and carrageenan properties of Chondracanthus teedei var. lusitanicus (Gigartinaceae, Rhodophyta). J. Appl. Phycol. 16, 369-383. doi: 10.1023/B:JAPH.0000047948.11892.67

Pomin, V. H., and Mourao, P. A. (2008). Structure, biology, evolution, and medical importance of sulfated fucans and galactans. Glycobiology 18, 1016-1027. doi: 10.1093/glycob/cwn085

Popper, Z. A., Michel, G., Hervé, C., Domozych, D. S., Willats, W. G. T., Tuohy, M. G., et al. (2011). Evolution and diversity of plant cell walls: from algae to flowering plants. Annu. Rev. Plant Biol. 62, 567-590. doi: 10.1146/annurevarplant-042110-103809

Préchoux, A., Genicot, S., Rogniaux, H., and Helbert, W. (2013). Controlling carrageenan structure using a novel formylglycine-dependent sulfatase, an endo4S-iota-carrageenan sulfatase. Mar. Biotech. 15, 265-274. doi: 10.1007/s10126012-9483-y

Robert, X., and Gouet, P. (2014). Deciphering key features in protein structures with the new ENDscript server. Nucl. Acids Res. 42, W320-W324. doi: 10.1093/nar/gku316

Sardiello, M., Annunziata, I., Roma, G., and Ballabio, A. (2005). Sulfatases and sulfatase modifying factors: an exclusive and promiscuous relationship. Hum. Mol. Genet. 14, 3203-3217. doi: 10.1093/hmg/ddi351

Sasaki, H., Yamada, K., Akasaka, K., Kawasaki, H., Suzuki, K., Saito, A., et al. (1988) cDNA cloning, nucleotide sequence and expression of the gene for arylsulfatase in the sea urchin (Hemicentrotus pulcherrimus) embryo. Eur. J. Biochem. $177,9-13$.

Seibert, C., and Raushel, F. (2005). Structural and catalytic diversity within the amidohydrolase superfamily. Biochemistry 44, 6383-6390. doi: 10.1021/bi047326v

Shin, M. H., Lee, D. Y., Wohlgemuth, G., Choi, L. G., Fiehn, O., and Kilm, K. H. (2010). Global metabolite profiling of agarose degradation by Saccharophagus degradans 2-40. New Biotechnol. 27, 156-168. doi: 10.1016/j.nbt.2010.02.023

Studier, F. W. (2005). Protein production by auto-induction in high-density shaking cultures. Prot. Exp. Pur. 41, 207-234. doi: 10.1016/j.pep.2005.01.016

Tamura, K., Peterson, D., Peterson, N., Stecher, G., Nei, M., and Kumar, S. (2011). MEGA5: molecular evolutionary genetics analysis using maximum likelihood, evolutionary distance, and maximum parsimony methods. Mol. Biol. Evol. 28, 2731-2739. doi: 10.1093/molbev/msr121

Tessier, D., Yclon, P., Jacquemin, I., Larré, C., and Rogniaux, H. (2010). OVNIp: an open source application facilitating the interpretation, the validation and the edition of proteomics data generated by MS analyses and de novo sequencing. Proteomics 10, 1794-1801. doi: 10.1002/pmic.200800783

Thrash, J. C., Cho, J. C., Vergin, K. L., Morris, R. M., and Giovannoni, S. J. (2010). Genome sequence of Lentisphaerae araneosa HTCC2155T, the type species of the order Lentisphaerales in the phylum lentisphaerae. J. Bacteriol. 192, 2938. doi: 10.1128/JB.00208-10

Usov, A. I. (2011). Polysaccharides of the red algae. Adv. Carbohydr. Chem. Biochem. 65, 115-217. doi: 10.1016/B978-0-12-385520-6.00004-2

van de Velde, F., Knutsen, S. H., Usov, A. I., Rollema, H. S., and Cerezo, A. S. (2002). ${ }^{1} \mathrm{H}$ and ${ }^{13} \mathrm{C}$ high resolution NMR spectroscopy of carrageenans: application in 
research and industry. Trends Food Sci. Technol. 13, 73-92. doi: 10.1016/S09242244(02)00066-3

Viladot, J. L., de Ramon, E., Durany, O., and Planas, A. (1998). Probing the mechanism of Bacillus 1,3-1,4-beta-D-glucan 4-glucanohydrolases by chemical rescue of inactive mutants at catalytically essential residues. Biochemistry 37 , 11332-11342.

Weigl, J., and Yaphe, W. (1966a). The enzymic hydrolysis of carrageenan by Pseudomonas carrageenovora: purification of a kappa-carrageenase. Can. J. Microbiol. 12, 939-947.

Weigl, J., and Yaphe, W. (1966b). Glycosulfatase of Pseudomonas carrageenovora: desulfation of disaccharide from $\mathrm{\kappa}$ - carrageenan. Can. J. Microbiol. 12, 874-876.

Whelan, S., and Goldman, N. (2001). A general empirical model of protein evolution derived from multiple protein families using a maximumlikelihood approach. Mol. Biol. Evol. 18, 691-699. doi: 10.1093/oxfordjournals.molbev.a003851

Yang, Q., Angerer, L. M., and Angerer, R. C. (1989). Structure and tissue-specific developmental expression of a sea urchin arylsulfatase gene. Dev. Biol. 135, 53-65.

Zablackis, E., and Santos, G. A. (1986). The carrageenan of Catenella-nipae Zanardini, a marine red alga. Bot. Mar. 29, 319-322.
ZoBell, C. E. (1941). Studies on marine bacteria. The cultural requirements of heterotrophic aerobes. J. Mar. Res. 4, 42-75.

Conflict of Interest Statement: The authors declare that the research was conducted in the absence of any commercial or financial relationships that could be construed as a potential conflict of interest.

Received: 24 June 2014; accepted: 03 August 2014; published online: 26 August 2014. Citation: Genicot SM, Groisillier A, Rogniaux H, Meslet-Cladière L, Barbeyron T and Helbert $W$ (2014) Discovery of a novel iota carrageenan sulfatase isolated from the marine bacterium Pseudoalteromonas carrageenovora. Front. Chem. 2:67. doi: 10.3389/fchem.2014.00067

This article was submitted to Chemical Biology, a section of the journal Frontiers in Chemistry.

Copyright (C) 2014 Genicot, Groisillier, Rogniaux, Meslet-Cladière, Barbeyron and Helbert. This is an open-access article distributed under the terms of the Creative Commons Attribution License (CC BY). The use, distribution or reproduction in other forums is permitted, provided the original author(s) or licensor are credited and that the original publication in this journal is cited, in accordance with accepted academic practice. No use, distribution or reproduction is permitted which does not comply with these terms. 